\title{
Crime and the Regional Disparities in Tourist Inflows: A Case Study of South Africa
}

\author{
${ }^{*}$ Busani Moyo, Olusegun. A. Akanbi \\ University of South Africa (UNISA), South Africa \\ *moyob@unisa.ac.za
}

\begin{abstract}
The aim of this study is to investigate the impact of crime proxied by different indicators on regional tourist inflows to South Africa. The estimations are carried out using the Johansen estimation techniques. Monthly data gathered from March 2003 to April 2011 is employed and the results from the estimations found that total crime has a negative effect on tourists from Africa, North America, Central and Southern America, West and Southern Europe. However, the level of crime in the country appears to have no influence at all to tourist from the Middle East whilst those from Asia are more sensitive to the level of sexual crime. At the different categories of crime investigated, tourists react differently. In line with the findings of the existing literature, the real exchange rate and world income remain to have a significant effect on tourist inflows from most of the regions.
\end{abstract}

Keywords: Inbound tourism, Crime and South Africa

\section{Introduction}

Tourism is regarded as a modern day engine of growth and is one of the largest growing industries globally. Being a labour-intensive sector, with a supply chain that links across sectors, tourism is vital for job creation, social inclusion, services exports and foreign exchange earnings as well as fostering a better understanding between peoples and cultures. It is also important to recognise that tourism plays a role in strategically creating and/or strengthening international relations in order to build beneficial socioeconomic and political networks. Therefore, investment in tourism has to be leveraged to contribute to national growth and sustainable development. In 2012, the G20 heads of state recognised tourism as a driver of growth and development, as well as a sector that has the potential to spur global economic recovery. The World Travel \& Tourism Council (WTTC, 2012) states that in 2011 the tourism sector contributed $9 \%$ of global gross domestic product (GDP), or a value of over US\$6 trillion, and accounted for about 255 million jobs which is about 6 - 7 percent of total employment worldwide. Over the period 2006 to 2011, World tourism's direct contribution to GDP grew on average at $1.2 \%$ per annum whilst the direct contribution to employment grew at $0.75 \%$ (see table 8 appendix). In 2011, the sector also account for about 4.8 percent of world exports and 9.2 percent of world investment. However, between the period 2006 and 2011, visitor exports and capital investment into the sector grew at an annual rate of $2.6 \%$ and $1.8 \%$ respectively. By 2022, it is anticipated that the sector will account for 328 million jobs or 1 in every 10 jobs on the planet and that the rate of growth of its contribution to GDP, employment, capital investment and exports will be at least $4 \%$ per annum (see table A1 in the appendix).

In Africa, tourism is the fastest developing enterprise and one of the continent's major investment opportunities, standing at a growth rate of 6 percent in the last decennium (COMESA, 2011). The COMESA (2011) report also states that Africa received 4.8 percent of all tourist arrivals in the world, 3.3 percent of the foreign exchange receipts and although it is not at the heart of the global tourist market, this modest proportion of the world's number one industry is still important for the continent. The World Tourism Council Statistics also show that the number of visitors to the African continent between 2007 and 2012 grew annually at an average rate of $2.7 \%$. The sector's direct contribution to GDP and employment also grew by $4.1 \%$ and 3\% respectively over the same period (see table 7 appendix). The countries in Africa that are performing well and are forecast to do well in future in the travel and tourism sector with regard to their contribution to employment, growth, visitor exports and capital investment include Nigeria, Namibia, North and South Sudan, Botswana, Malawi, Cape Verde, Papua New Guinea, Zambia, Tunisia, Gambia and Seychelles (World Tourism Council, 2012). Although South Africa does not currently feature among the top performers in Africa, the government has earmarked tourism as a key sector with excellent potential for growth and aims to increase tourism's contribution (both directly and indirectly), to the economy from the 2009 baseline of R189,4-billion (7.9\% of GDP) to R499-billion by 2020 (National 
Department of Tourism, 2012). Tourism supports one in every 12 jobs in South Africa and the country's spectacular scenery, magnificent outdoors, sunny climate, cultural diversity, friendly people, and worldclass infrastructure makes it one of the most desired destinations in the world. Thus tourism is one of the five priority economic sectors that the government has chosen to focus on in its effort to support investment and facilitate growth. The sector is currently performing well relative to other priority sectors and is often referred to as the 'new gold' of the South African economy, partly due to the fact that total foreign direct spend of tourists has overtaken gold foreign exchange earnings (The DTI, Investor's Handbook, 2010).

The World Council of Tourism (2012) statistics also show that the number of visits coming into the country has been growing at about $2.7 \%$ per annum over the period 2007 to 2012 . Stats SA statistics also show that the number of tourist coming to South Africa in the past four decades has generally been increasing even though the total number of visitors only surpassed a million mark in the 1990s (Stats SA, 2010). Thus for the period 1980 to 1992 prior to the democratic elections, tourist visits increased by about 14\% per year, rising to about 33\% between 1992 and 2009 (Stats SA, 2010). The direct contribution to GDP and employment also grew at $4.4 \%$ and $3 \%$ respectively. The country has also been investing a lot in tourism related facilities and the rate of growth of capital investment into the sector was also about 3\% per annum between 2007 and 2012. The government is also driving for the rate of growth of tourism's contribution to GDP to grow by $5.1 \%$ by 2020 with capital investment growing at $4.3 \%$ and tourist arrivals at $4.5 \%$ (see table A2 appendix). In South Africa, foreign visitor ${ }^{1}$ arrivals still generate a larger tourism spend than the domestic market, and thus, the dependence on foreign visitor arrivals renders the industry vulnerable to external shocks. Thus this vulnerability implies that measures need to be taken to promote alternative domestic tourism or the government and tourism officials should continue to ensure that foreign visitors have a memorable experience when in the country. Although the number of tourists visiting South Africa has been increasing, serious concerns have been raised about the level of crime in the country. In the media, South Africa is listed among the world's most violent nations outside a war zone and is also regarded as the rape capital of the world (Ferreira and Harmse, 2000). The World Economic Forum, Travel and Tourism Competitiveness Report (2009) also indicates that South Africa's weakest areas include safety and security, access to health services, as well as human resources, which include qualified labour.

These perceptions though in most cases unsubstantiated are harmful to the country's efforts to attract and boost the tourism industry. Crime statistics from the South African Police Services (SAPS) show that the total number of serious crimes has been gradually decreasing from 2001 up to 2010 . Thus these crime cases have declined by about 18\% between 2001 and 2010 (SAPS, 2011 report). Between 2003 and 2010, the number of murder cases fell by $19 \%$ whilst sexual crimes increased by $1.1 \%$, illegal possession of firearms cases fell by $16.7 \%$ but kidnapping cases increased by $18.7 \%$. Other crimes like public violence, culpable homicide, and drug-related crime, theft of and from motor vehicles as well as common assault to inflict grievous bodily harm also appear to be on an upward trend (see table A4, appendix). According to George (2002) perception of high crime rate, mostly reported by media have discouraged both international and domestic tourists from visiting scenic popular destinations. This is supported by Lew (1987) who notes that "image is the most important aspect of a tourist attraction". Altindag (2010) argues that individuals do not have a true measure of victimization risk in the destination country; they only have a perception about it. He goes on to argue that this ex-ante expectation about being victimized in the destination country can be formed by obtaining information through various channels, such as print or electronic media or word-of-mouth. Regardless of the source of the information, the actual crime rate in the destination country can be a proxy for the perceived risk of being victimized (Altindag 2010). Levantis and Gani (2000) also add that law and order problems may affect the demand for tourism through the impact on prices for tourist services. Thus tourism service providers in crime prone countries experience cost increases in the form of higher insurance premiums, higher losses against businesses and

\footnotetext{
${ }^{1}$ Most of these visitors to South Africa come from mainland Africa particularly SADC whilst overseas tourists come from Europe, North America and Asia.
} 
increases in the provision of security measures resulting in them passing over these costs to consumers of tourism services.

The aim of this study therefore is to examine the nature of relationship between crime and the tourist inflows to South Africa. Thus we want to find out whether crime has affected the performance of the tourism sector in the country. We will also go further and disaggregate our tourist inflows data into regions as well as our crime data into various types of violent crimes and study how tourists from different regions of the world (Africa, Europe, North America etc) are affected by these crime incidences in South Africa? Thus, the question that we want to answer is: are the geographical disparities in tourist inflows to the country influenced by the levels of crime? Which region is more sensitive to crime levels in the country and which type(s) of crimes are visitors sensitive to? The motivation is that all government efforts to use tourism as a driver of growth, help in the transition to a green economy, for employment creation, and as a source for foreign exchange earnings etc are only realizable if a conducive environment is created where tourists not only get value for their money but also feel safe and secure. If visiting a country results in tourists risking their lives then it does not matter whether you have a spectacular scenery, magnificent outdoors, sunny climate, impressive cultural diversity, tourists will not choose to visit the country. We disaggregate crime partly along the lines of what Ferreira and Harmse (2000) called the "big six": sexual crimes, car hijackings and robbery, illegal possession of fire arms, murder and finally kidnapping. Our argument is that, tourists would be afraid of visiting a country where there is a high probability of being sexually assaulted, hijacked and robbed of personal valuables or belongings as well as where individuals are easily accessible to unlicensed firearms.

We also include all crimes recorded by the SAPS in the whole country to ascertain whether the general crime level matter to tourists or not. In disaggregating our tourist inflow data, we have grouped our geographical tourist source countries into five (5) regions namely Europe, North America, South and Central America, Africa, Asia and the Middle East. These regions are the main sources of tourist inflows into the country. The other motivation for this research is that very little has been done in studying the impact of crime on tourism demand in Africa particularly in South Africa ${ }^{2}$. The only recent studies on crime in South Africa (qualitative in nature) was done by Nkosi (2010) who looked at the impact of crime on tourism in the city of Umhlathuze, KwaZulu-Natal whilst Moyo and Ziramba (2013) only looked at the impact of the "big six" crimes on total tourist inflows without going deeper into regional disparities as is the case in this study. The paucity of studies on crime may partly be explained by the unavailability of reliable crime data in many African countries. The results from this study show that total crime has a negative effect on tourists from Africa, North America, Central and Southern America, West and Southern Europe. However, the level of crime in the country appears to have no influence at all to tourist from the Middle East whilst those from Asia are more sensitive to the level of sexual crime. This study is organized as follows; the next section provides a review of empirical literature and is followed by section 3 where the theoretical framework, methodology and data measurement are discussed. Sections 4 and 5 cover results presentation and analysis as well as conclusions respectively.

\section{Literature Review}

Although there are a number of empirical studies that have been done to review the determinants of international tourism demand, very few of these studies look at the impact of crime on inbound tourism particularly in Africa (see Ferreira S and Harmse A, 2000; Nkosi, 2010, Moyo and Ziramba, 2013). Boxill (1995) used a multiple regression model to examine the impact of violent crime on tourist arrivals in Jamaica. The findings showed that the violent crime rate was not a good predictor of tourism arrivals in Jamaica. In fact the violent crime rate explained less than $5 \%$ of the variation in the tourist arrivals in the country. However, according to Alleyne and Boxill (2003) this study had a number of methodological limitations. For example, a linear model was used and this would have been insensitive to a possible nonlinear relationship between crime and tourist arrivals. Alleyne and Boxill (2003) examined the

\footnotetext{
${ }^{2}$ Ferreira and Harmse (2000) used cases of serious violent crimes against international tourists that were reported in the press from January 1997 to December 1998. They analyzed the general crime pattern using the "big six crimes": public violence, rape, murder and aggravated assault, burglary, robbery and motor vehicle theft) found that violent crime, as is the case in South Africa, is a big deterrent for tourists. Their analysis was however descriptive in nature and did not interrogate rigorously the impact of crime on tourism. The same is also true for Nkosi G (2010).
} 
relationship between tourist arrivals and changes in the crime rate in Jamaica over the period 1962-1999 using a transfer function. The transfer function that they used allows for the modelling of the immediate and delayed effects of crime rates on tourist arrivals from Europe and North America. They found that crime rates have a negative impact on tourism arrivals in both markets, and is particularly of greater concern in the European market. Levantis and Gani (2000) tested the effect of crime on the demand for tourism across eight developing nations of the Caribbean between the period 1970 and 1993. They found that if a nation is suffering a deteriorating law and order problem relative to other nations in the region, then the demand for tourism to that nation will be adversely affected. Thus their empirical results confirm the importance of crime levels as a hindrance to the demand for tourism, the inference being that news of a deteriorating law and order situation in destination countries is being successfully disseminated to potential tourists in source countries despite the general inaccessibility of up-to-date crime statistics.

Altindag (2010) using a panel data set of 34 European countries covering the years 1995 to 2003, investigated the impact of crime on international tourism and found that violent crimes are negatively associated with incoming international tourists and international tourism revenues. The author specifically found that violent crimes (homicide, rape, robbery and assault) are negatively associated with incoming international tourists and with tourism revenue for an average country in Europe whilst aggregate property crime or its components (theft and burglary) do not have a significant influence. This indicates that international tourists consider the risk of victimization when choosing a location to visit. However, the pioneering studies on the relationship between tourism and crime that began with the work of Jud (1975) and Pizam (1982) looked at the impact of tourism on crime not the impact of crime on tourist arrivals. Thus Jud(1975) in examining this relationship in a cross section of 32 Mexican states found that property related offenses (fraud, larceny, and robbery) were more strongly and positively related to tourism, while violent offenses were only marginally associated with it. However, Pizam (1982) found very little linkage between tourism and crime in a nationwide survey of the United States, although his later cross-cultural study (Pizam and Telisman-Kosuta 1989) revealed that tourism was perceived to lead to an increase in organized crime. This positive relationship is explained by the fact that when tourist arrivals increase, the number of people in circulation will increase, thus more victims and the crime rate will increase (Harper, 2000).

Biagi et al (2012) using a system Generalized Methods of Moments (GMM) approach for the time period 1985-2003, empirically tested whether total crime in Italy is affected by tourist arrivals. Their findings also confirmed the general positive relationship between tourism and crime in destinations. They argued that agglomeration and urbanization effects seem to be the main explanation for the impact of tourism on crime. These studies on crime basically suggest that the relationship between crime and tourism is not unidirectional and therefore may suffer from the problem of endogeneity. Following Corman and Mocan (2000) and Levitt (1998), crime rate is lagged by one year to avoid potential reverse causality. The rationale behind this approach is that tourists that visit a country in a specific year cannot influence the crime rate of that country in the previous year ${ }^{3}$. The other reason is that tourists visiting a particular destination use the previous period crime statistics to inform their perceptions about the host country's safety and security. Moyo and Ziramba (2013) investigated the impact of crime proxied by different indicators on tourist inflows to South Africa using an ARDL bounds test. Using monthly crime data from April 2003 to March 2011 obtainable from the South Africa Police Services and Statistics South Africa, they found that crime in the form of car hijackings, illegal possession of firearms, murder and kidnapping have a long run and short run negative impact on tourist visits to South Africa.

\section{Methodology}

Following the empirical literature, our aggregate inbound tourism demand model for South Africa assumes that total tourist inflows to South Africa are a function of the level of real income, the real exchange rate and lagged value of crime indicators. The use of the lagged value of crime is based on the notion that once tourists are affected by crime at a destination, their motivation to revisit will be highly distorted. We specify our aggregate inbound tourism demand model for South Africa as follows:

\footnotetext{
${ }^{3}$ This could be used to avoid endogeneity problems characteristic of crime and tourist inflows.
} 
$\ln \_$tourist $t_{t}=\beta_{0}-\beta_{1} \ln \_w g d p_{t}+\beta_{2} \ln \_$rexch $-\beta_{3} \ln \_$crime t $_{t-1} \pm \varepsilon_{t}$

Where 'tourist' is the aggregate tourist flows into South Africa from a particular region in month $t$, 'wgdp' is real world income (real GDP) proxied by weighted average of monthly unemployment rate, 'rexch' is the real exchange rate of the rand, 'crime' is the reported number of criminal cases, and $\varepsilon$ is the regression residual. The estimated parameter coefficients represent elasticities. An increase in real world income is expected to generate more employment (decline in unemployment) as it results in higher economic activity. The coefficient of income, $\beta_{1}$ is therefore expected to be negative. Coefficient $\beta_{2}$ is expected to be positive. As the rand depreciated in real terms, it will be less expensive for tourists to visit South Africa and thereby leading to more inflow of tourists. The coefficient $\beta_{3}$ on the crime variables is also expected to be negative. Thus high levels of crime may scare away potential tourists and thus result in a decline in tourist inflows.

In line with the Johansen (1988) cointegration estimation technique, the reduced-form Vector Autoregression (VAR) of Equation (1) is re-specified as:

$X_{t}=\beta_{0}+\beta_{1} X_{t-1}+\ldots .+\beta_{j} X_{t-j}+\varepsilon_{t}$

Where $X_{t}$ is a vector of variables;

$$
X_{t}^{\prime}=\left[\ln \_w g d p_{t}, \ln \_r \text { rexch }_{t}, \ln \_ \text {crime }_{t-1}, \ln \_ \text {tourist }_{t}\right]
$$

Cholesky decomposition is utilised for orthogonalisation, which means that Cholesky factor is lowered triangular. Therefore, the tourist inflow variable will be contemporaneously affected by all the other variables. Based on the long-run relationship that is captured by the tourist demand model specified in Equation (1), a vector error correction model (VECM) of the following form is estimated to reveal the short-run dynamics in the tourist demand function.

$$
\Delta X_{t}=\pi X_{t-1}+\sum_{i=1}^{p-1} \pi_{i} \Delta X_{t-i}+\varepsilon_{t}
$$

The estimation procedure is as follows. Firstly, the reduced-form VAR in Equation (4) is estimated and all the diagnostic tests are performed. Secondly, the Johansen cointegration test is performed and the cointegrating vectors and loading matrices are identified. Thirdly, a VECM from Equation (4) is estimated and the entire range of diagnostic tests is performed. ${ }^{4}$

The study uses monthly time series data from April 2003 to March 2011 thus providing 96 data points. As mentioned above, the dependent variable is international holiday visits or tourists arrivals to South Africa from different selected regions. The data for this variable was obtained from the Stats SA monthly tourism and migration reports. From the literature, taste formation, domestic prices, foreign prices and income levels in the country are identified as important determinants of international tourism demand. The real exchange rate is used as a proxy for domestic prices whilst world income was proxied by the weighted monthly unemployment rate. The paper uses proxies to capture these variables. Monthly data on crime for the period was obtained from the Quantec database. Monthly data on income is not available. However, since the effects of changes in global economic activity is directly reflected on the level of global unemployment, the average weighted monthly United States, Japan, Germany, UK, Russia, Brazil, China and France unemployment rates (obtained from the IMF) is used as a proxy for changes in income ${ }^{5}$ Our main independent variable crime is measured in six ways using total crimes reported, car hijackings, illegal possession of fire arms, kidnapping, murder and sexual offenses. We selected violent crimes only because they have a long term devastating physical, emotional and psychological effects on the victims and thus may greatly impact negatively on tourist inflows. The after effects of violent crime in the form of posttraumatic stress disorders, paranoia, long term financial problems, emotional imbalance that causes anxiety attacks, flashbacks etc paint a scary picture of crime victims and will thus discourage tourists from visiting crime prone areas.

\footnotetext{
${ }^{4}$ The VAR passed all the diagnostic tests, revealing a well-specified model. These tests results are available on request.

${ }^{5}$ We constructed the weighted average of unemployment variable using the principal component analysis (PCA)
} 


\section{Results and Analyses}

As discussed earlier, the focus of the study is to establish the impact of crime on tourist inflows into South Africa after controlling for other factors that affect tourist inflows to the country. Given the disparity in the nature of criminal offences, the study further investigate the impact of five major crime offences as highlighted in Ferreira and Harmse (2000). Therefore, each regional tourist inflows investigation will require six different estimated equations.

The nature of the data used in this study suggests non-stationarity at level form but stationary at first difference except for crime and tourists data which are found to be trend stationary at level form. ${ }^{6}$ Therefore, based on the nature of the data-generating process of all four variables, an appropriate model for inbound tourist demand for South Africa is selected.7 The appropriate model allow for a linear deterministic trend in the data with a constant (no trend) in cointegrating equation and VAR. To test which version of the deterministic component is appropriate, the Pantula principle is followed, and the trace test and the maximum eigenvalue test identified at least one cointegrating vector for a model with constant (no trend) in the cointegrating equation. For each cointegrating test result, there exists one cointegrating vector in either the trace test or the maximum eigenvalue test. However, in a conflicting cointegrating scenario where there exists more than one cointegrating vector in any of the two tests statistics, the maximum eigenvalue test is adopted when estimating the error correction model as it has a sharper alternative hypothesis that pins down the number of cointegrating vectors (Enders, 2004:354). ${ }^{8}$ Using the cointegrating test results, the long-run part of the VECM is presented in Equation (5). The longrun cointegrating vector identified the tourist demand, which is the equation of interest in this study.

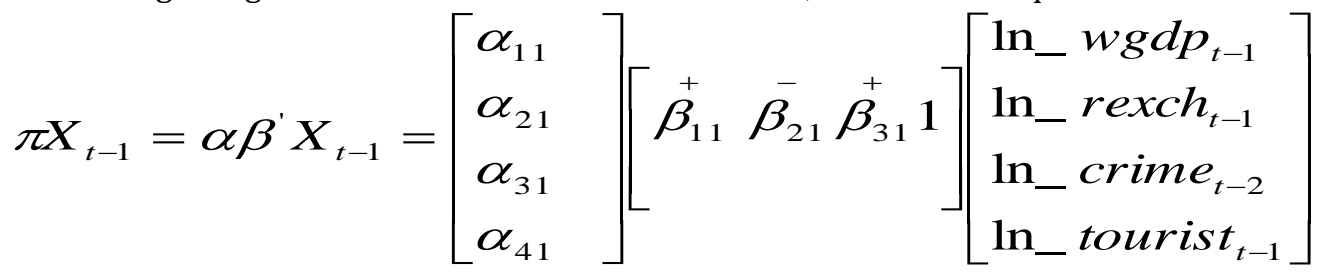

Where $\beta^{\prime}$ represents the long-run coefficients, and $\alpha^{\prime}$ are the short-run adjustment coefficients in the VECM. After normalisation, the estimated long-run inbound tourism demand equations are presented in Table 1 to 9 with t-values in parentheses.

Table 1: Estimated long-run results for all tourists from all regions

\begin{tabular}{|c|c|c|c|c|c|c|}
\hline & \multicolumn{6}{|c|}{ Dependent variable: Total tourists inflows from all regions } \\
\hline & Model 1 & Model 2 & Model 3 & Model 4 & Model 5 & Model 6 \\
\hline $\begin{array}{l}\text { World GDP (Proxy: } \\
\text { weighted unemplovment) }\end{array}$ & $\begin{array}{l}-0.53^{* * *} \\
(-6.47)\end{array}$ & $\begin{array}{l}-0.88^{* * *} \\
(-6.89)\end{array}$ & $\begin{array}{l}-0.53^{* * *} \\
(-5.99)\end{array}$ & $\begin{array}{l}-0.61 * * \\
(-2.63)\end{array}$ & $\begin{array}{l}-0.69 * * * \\
(-11.42)\end{array}$ & $\begin{array}{l}-0.91^{* * *} \\
(-8.24)\end{array}$ \\
\hline $\begin{array}{l}\text { weighted unemployment) } \\
\text { Real exchange rate (R/\$) }\end{array}$ & $\begin{array}{l}(-6.47) \\
0.74^{* * *} \\
(5.19)\end{array}$ & $\begin{array}{l}(-6.89) \\
1.55^{* * *} \\
(10.14)\end{array}$ & $\begin{array}{l}(-5.99) \\
1.05^{* * *} \\
(8.92)\end{array}$ & $\begin{array}{l}(-2.63) \\
1.55^{* * *} \\
(7.82)\end{array}$ & $\begin{array}{l}(-11.42) \\
0.84^{* * *} \\
(716)\end{array}$ & $\begin{array}{l}(-8.24) \\
1.79^{* * *} \\
(13.35)\end{array}$ \\
\hline Total crime & $\begin{array}{l}-0.92^{* * *} \\
(-4.91)\end{array}$ & & & & & \\
\hline Car hijack & & $\begin{array}{l}-0.23 \\
(-1.25)\end{array}$ & & & & \\
\hline Firearms & & & $\begin{array}{l}-0.75^{* * *} \\
(-4.20)\end{array}$ & & & \\
\hline Kidnap & & & & $\begin{array}{l}-0.28 \\
(-1.21)\end{array}$ & & \\
\hline Murder & & & & & $\begin{array}{l}-0.56^{* * *} \\
(-5.88)\end{array}$ & \\
\hline Sex & & & & & & $\begin{array}{l}0.78^{* * *} \\
(13.37)\end{array}$ \\
\hline Constant & 21.21 & 8.91 & 14.81 & 9.73 & 13.86 & 40.43 \\
\hline
\end{tabular}

Note: *** Significant at $1 \%$ level; ${ }^{* *}$ Significant at $5 \%$ level; ${ }^{*}$ Significant at $10 \%$ level

Source: Author's calculations and analysis of data

\footnotetext{
${ }^{6}$ Results of the unit root tests for all the variables used in the study and the reduced-form VAR diagnostic tests are presented and analysed in the Appendix.

${ }^{7}$ Trace and maximum eigenvalue tests results used for this study are available on request

${ }^{8}$ Most of the maximum eigenvalue test statistics identified one cointegrating vector.
} 
The results for all tourists from all regions are found to be statistically and economically significant and are consistent with the theoretical specification in equation (1) except for model 6 where sex crime seems not to be a threat to tourists (Table 1). Despite the rising level of sex crime in the country total inflow of tourists tend to increase. In terms of total crime, tourist's inflows will decline by about $0.92 \%$ when total level of crime rises by about a 1\%. Car hijack and kidnap crimes seems to exert lesser force on tourist inflows by about $0.23 \%$ and $0.28 \%$ decline respectively and are found to be statistically insignificant. However, tourists are more concerned with the firearms and murder crimes level in the country. A $1 \%$ increase in the level of firearms crimes in the previous period will lead to about $0.75 \%$ decline in total tourist inflows while this will lead to about $0.56 \%$ decline in the case of murder crimes. As global output (GDP) rises, the level of unemployment is expected to fall. Therefore, the impact of a $1 \%$ increase in global unemployment will range from $0.53 \%$ to $0.91 \%$ decline in total tourist inflow to South Africa. As the exchange rate depreciates in real terms, decision by tourist to visit South Africa for holiday rises. Therefore, the impact of rising exchange rate by $1 \%$ (depreciation) will range from about $0.74 \%$ to $1.79 \%$ increase in tourist inflow.

Table 2: Estimated long-run results for African tourists

\begin{tabular}{|c|c|c|c|c|c|c|}
\hline & \multicolumn{6}{|c|}{ Dependent variable: African tourists inflows } \\
\hline & Model 1 & Model 2 & Model 3 & Model 4 & Model 5 & Model 6 \\
\hline $\begin{array}{l}\text { World GDP (Proxy: weighted } \\
\text { unemployment) }\end{array}$ & $\begin{array}{l}-0.68^{* * *} \\
(-10.25)\end{array}$ & $\begin{array}{l}-1.18^{* * *} \\
(-7.49)\end{array}$ & $\begin{array}{l}-0.73^{* * *} \\
(-9.54)\end{array}$ & $\begin{array}{l}-1.17^{* * *} \\
(-3.40)\end{array}$ & $\begin{array}{l}-0.91 * * * \\
(-18.00)\end{array}$ & $\begin{array}{l}-1.37^{* * *} \\
(-6.75)\end{array}$ \\
\hline Real exchange rate $(\mathrm{R} / \$)$ & $\begin{array}{l}0.91^{* * *} \\
(5.49)\end{array}$ & $\begin{array}{l}1.84^{* * *} \\
(9.93)\end{array}$ & $\begin{array}{l}1.37^{* * *} \\
(12.53)\end{array}$ & $\begin{array}{l}2.15^{* * *} \\
(7.11)\end{array}$ & $\begin{array}{l}0.98^{* * *} \\
(8.72)\end{array}$ & $\begin{array}{l}2.03^{* * *} \\
(13.00)\end{array}$ \\
\hline Total crime & $\begin{array}{l}-0.96^{* * *} \\
(-4.53)\end{array}$ & & & & & \\
\hline Car hijack & & $\begin{array}{l}-0.23 \\
(-1.11)\end{array}$ & & & & \\
\hline Firearms & & & $\begin{array}{l}-0.52^{* *} \\
(3.11)\end{array}$ & & & \\
\hline Kidnap & & & & $\begin{array}{l}0.54 \\
(1.47)\end{array}$ & & \\
\hline Murder & & & & & $\begin{array}{l}-0.56^{* * *} \\
(-5.68)\end{array}$ & \\
\hline Sex & & & & & & $\begin{array}{l}1.84^{* *} \\
(3.07)\end{array}$ \\
\hline Constant & 20.57 & 7.07 & 11.56 & 1.93 & 12.49 & 11.49 \\
\hline
\end{tabular}

Note: *** Significant at $1 \%$ level; ${ }^{* *}$ Significant at $5 \%$ level; ${ }^{*}$ Significant at $10 \%$ level

Source: Author's calculations and analysis of data

Looking at tourists from other African countries, global economic activity and exchange rate fluctuations remained significant factors in the decision of tourists visit for a holiday in South Africa (Table 2). Despite similar crime levels in these countries in comparison with South Africa, tourists are still concerned about the level of crime when visiting the country. A 1\% increase in the total level of crime will lead to about $0.96 \%$ decline in tourist inflows from other African countries. Kidnaps and sex crimes are not major threats to African tourists. Tourist's inflows will continue to rise despite the rising levels of kidnaps $(0.54 \%)$ and rape $(1.84 \%)$ in the country. On the other hand, a $1 \%$ increase in car hijack, firearms and murder crimes will lead to about $0.23 \%, 0.52 \%$ and $0.56 \%$ decline in tourist inflows from other African countries respectively. The irresistible nature of African tourists to crime level in South Africa could be attributed to the violent-type of crime that exist in the country which are rare in other African countries.

Table 3: Estimated long-run results for Asian tourists

\begin{tabular}{lllllll}
\hline & \multicolumn{2}{l}{ Dependent variable: Asian tourists inflows } & & \\
& Model 1 & Model 2 & Model 3 & Model 4 & Model 5 & Model 6 \\
\hline World GDP (Proxy: weighted & -0.19 & $-0.46^{* *}$ & $-0.25^{*}$ & $-0.78^{* * *}$ & $-0.67^{* * *}$ & $0.54^{* * *}$ \\
unemployment) & $(-1.31)$ & $(-3.57)$ & $(-1.72)$ & $(-7.36)$ & $(-4.27)$ & $(3.59)$ \\
Real exchange rate (R/\$) & $1.56^{* * *}$ & $1.44^{* * *}$ & $1.56^{* * *}$ & $1.21^{* * *}$ & 0.20 & $0.82^{* * *}$ \\
& $(4.72)$ & $(9.09)$ & $(7.53)$ & $(11.85)$ & $(0.54)$ & $(4.71)$ \\
Total crime & -0.15 & & & & & \\
Car hijack & $(-0.38)$ & & & & & \\
Firearms & & $-0.46^{* *}$ & & & &
\end{tabular}




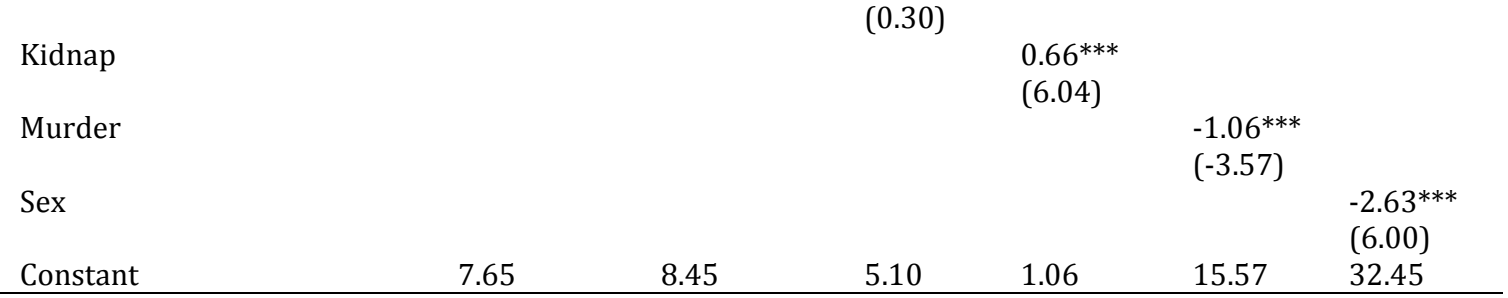

Note: ${ }^{* *}$ Significant at $1 \%$ level; ${ }^{* *}$ Significant at $5 \%$ level; ${ }^{*}$ Significant at $10 \%$ level Source: Author's calculations and analysis of data

Tourist inflows from Asia are more negatively affected by the level of sex crime in the country. A 1\% increase in the level of sex crime will make Asian tourists visit for holiday in South Africa to decline by about $2.6 \%$ (Table 3). The level of income (unemployment) seems to have a negative impact $(-0.54 \%)$ when sex crime alone featured in the model. This indicates a dominating effect of sex crime and that Asian tourists can ignore the income effect when sex crime is rising. The effect of total crime on tourist's inflows from Asia is found to be insignificant. A $1 \%$ increase in total crime level will lead Asian visits to South Africa for holiday to decline by about $0.15 \%$. Car hijack and murder are also a major concern to Asian tourists with a respective $0.46 \%$ and $1.06 \%$ decline in inflows. On the other hand, a rising level of firearms and kidnap crimes by $1 \%$ will lead to about $0.08 \%$ and $0.66 \%$ increase in tourist inflows respectively.

Table 4: Estimated long-run results for Middle-east tourist from all regions

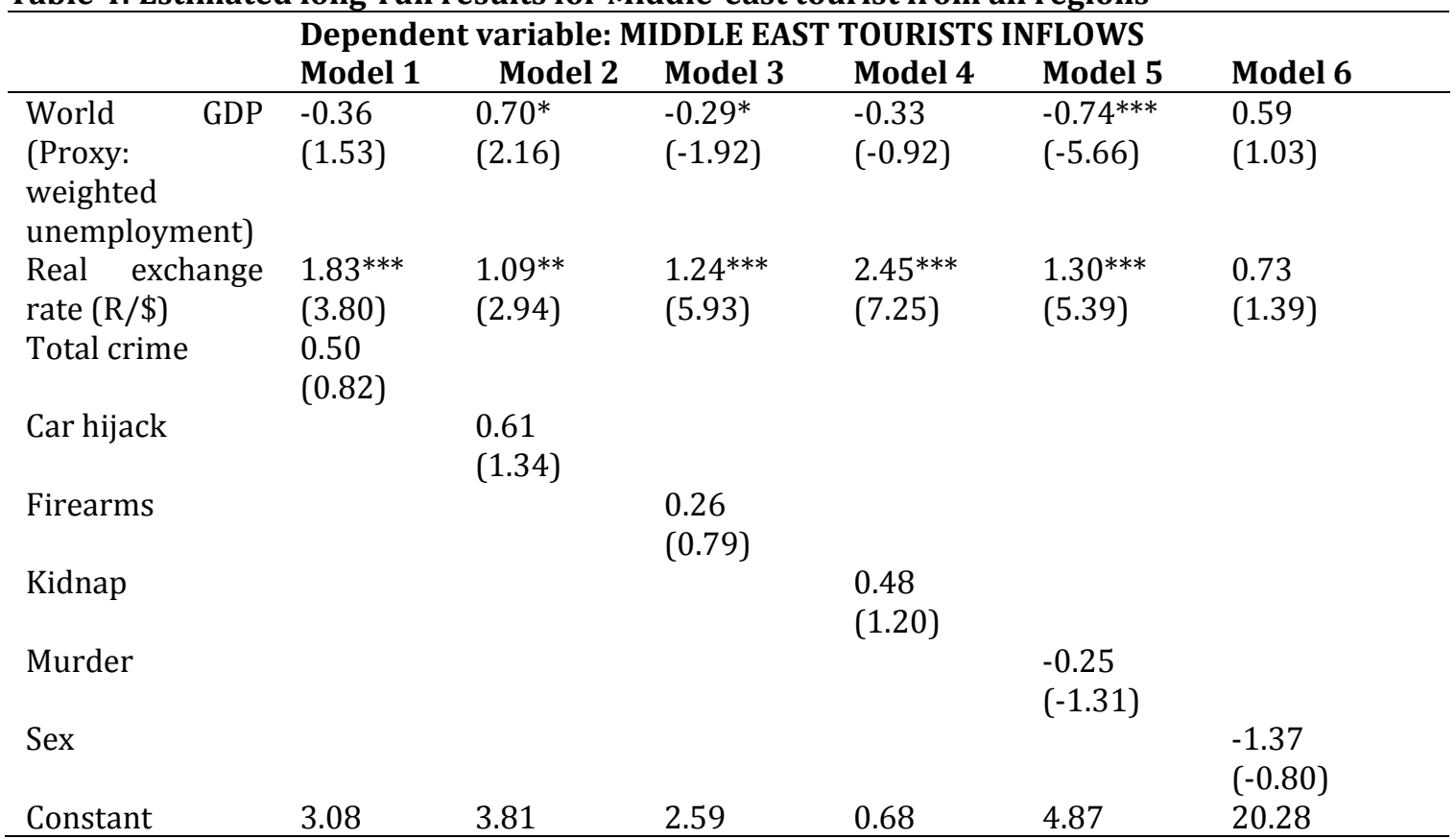

Note: ${ }^{* * *}$ Significant at $1 \%$ level; ${ }^{* *}$ Significant at $5 \%$ level; ${ }^{*}$ Significant at $10 \%$ level

Source: Author's calculations and analysis of data

The impact of crime on tourist inflows to the country from the middle-east is found to be statistically insignificant across the major types of crimes. In general, the level of crime in the country does not negatively influence middle-east tourist's inflows. When the total crime level rises by $1 \%$ tourist's inflows from the middle-east will increase by about $0.5 \%$ (see table 4). Similar trend ensue for car hijack, firearms and kidnap. Murder and sex crimes are threats to tourists from this part of the world. A $1 \%$ rise in murder rate will lead to about $0.25 \%$ decline in inflow of tourists from the middle-east while this will exert about $1.37 \%$ decline in relation to sex (rape) crime. The similarities in the impact of sex crime on tourist inflows between Asian and middle-east tourists could be attributed to the close proximity of the two regions. 
Table 5: Estimated long-run results for North American tourists

\begin{tabular}{|c|c|c|c|c|c|c|}
\hline & \multicolumn{6}{|c|}{ Dependent variable: North American tourists inflows } \\
\hline & Model 1 & Model 2 & Model 3 & Model 4 & Model 5 & Model 6 \\
\hline World $\quad$ GDP $\quad$ (Proxy: & -0.09 & $-0.61^{* * *}$ & $-0.37^{* * *}$ & $-0.87^{*}$ & $-0.61^{* * *}$ & $-0.68^{* * *}$ \\
\hline weighted unemployment) & $(-0.78)$ & $(-4.05)$ & $(-2.49)$ & $(-2.97)$ & $(-9.66)$ & $(-6.24)$ \\
\hline Real exchange rate $(\mathrm{R} / \$)$ & $\begin{array}{l}0.62^{* *} \\
(2.65)\end{array}$ & $\begin{array}{l}1.66^{* * *} \\
(12.79)\end{array}$ & $\begin{array}{l}1.38^{* * *} \\
(6.82)\end{array}$ & $\begin{array}{l}2.12^{* * *} \\
(8.33)\end{array}$ & $\begin{array}{l}0.52^{* * *} \\
(3.83)\end{array}$ & $\begin{array}{l}1.78^{* * *} \\
(12.30)\end{array}$ \\
\hline Total crime & $\begin{array}{l}-1.23^{* * *} \\
(-4.35)\end{array}$ & & & & & \\
\hline Car hijack & & $\begin{array}{l}-1.10^{* * *} \\
(-5.20)\end{array}$ & & & & \\
\hline Firearms & & & $\begin{array}{l}-0.42 \\
(-1.47)\end{array}$ & & & \\
\hline Kidnap & & & & $\begin{array}{l}0.43 \\
(1.44)\end{array}$ & & \\
\hline Murder & & & & & $\begin{array}{l}-0.87^{* * *} \\
(-7.84)\end{array}$ & \\
\hline Sex & & & & & & $\begin{array}{l}0.49^{* * *} \\
(8.25)\end{array}$ \\
\hline Constant & 23.46 & 12.40 & 9.03 & 0.55 & 13.97 & \\
\hline
\end{tabular}

Results for tourists from North America follows similar trend with that of African tourists except that the impact is larger at the total crime level and in some other types crime. A $1 \%$ increase in the total level of crime will lead to about $1.23 \%$ decline in tourist inflows from North America (Table 5). Kidnaps and sex crimes are not major threats to this group of tourists. Tourist's inflows will continue to rise despite the rising level of kidnaps $(0.43 \%)$ and sex $(0.49 \%)$ crimes in the country. On the other hand, a $1 \%$ increase in car hijack, firearms and murder crimes will lead to about $1.1 \%, 0.42 \%$ and $0.87 \%$ decline in tourist inflows from North America respectively.

Table 6: Estimated long-run results for Central \& South American tourists

\begin{tabular}{|c|c|c|c|c|c|c|}
\hline & \multicolumn{6}{|c|}{ Dependent variable: Central \& South American tourists inflows } \\
\hline & Model 1 & Model 2 & Model 3 & Model 4 & Model 5 & Model 6 \\
\hline World GDP & $0.87^{* *}$ & -0.02 & $1.04^{* *}$ & -0.04 & $0.40^{*}$ & $1.40^{* * *}$ \\
\hline weighted unemployment) & $(3.28)$ & $(-0.06)$ & $(3.51)$ & $(-0.08)$ & $(2.40)$ & $(4.46)$ \\
\hline Real exchange rate $(\mathrm{R} / \$)$ & $1.70^{* *}$ & $2.72^{* * *}$ & $1.83^{* * *}$ & $3.03^{* * *}$ & $1.22^{* *}$ & $1.82^{* * *}$ \\
\hline & $(2.97)$ & $(5.79)$ & $(4.33)$ & $(6.40)$ & $(3.47)$ & $(5.11)$ \\
\hline Total crime & -1.19 & & & & & \\
\hline Car hijack & & $\begin{array}{l}-0.33 \\
(-0.65)\end{array}$ & & & & \\
\hline Firearms & & & $\begin{array}{l}-0.76 \\
(-1.27)\end{array}$ & & & \\
\hline Kidnap & & & & $\begin{array}{l}0.49 \\
(0.89)\end{array}$ & & \\
\hline Murder & & & & & $\begin{array}{l}-1.04^{* *} \\
(3.61)\end{array}$ & \\
\hline Sex & & & & & & $\begin{array}{l}-2.73^{* *} \\
(-3.03)\end{array}$ \\
\hline Constant & 22.34 & 5.21 & 13.59 & -0.45 & 15.68 & 33.03 \\
\hline
\end{tabular}

Note: *** Significant at 1\% level; ** Significant at 5\% level; * Significant at $10 \%$ level

Source: Author's calculations and analysis of data

Tourist inflows from Central \& South America are negatively affected by all the types of crime in the country except for kidnap. A $1 \%$ increase in the total level of crime will lead to about $1.19 \%$ decline in tourist inflows from Central \& South America (Table 6). Similar to other regions, Kidnaps crimes are also not major threats to this group of tourists. A $1 \%$ rise in kidnap will lead to about $0.49 \%$ increase in tourist inflow to the country from Central \& South America. All other types of crime will exert a negative force on tourist inflows with a statistical insignificance in relation to firearms (0.76) and car hijack (0.33). Sex crime is found to be major threats to this group of tourist. A $1 \%$ rise in sex crime will lead to about $2.73 \%$ decline in tourist inflow from Central \& South America while 1.04\% decline will be recorded with regards to murder crime. On the other hand, a 1\% increase in car hijack, firearms and murder crimes will lead to 
about $1.1 \%, 0.42 \%$ and $0.87 \%$ decline in tourist inflows from North America respectively. However, income effect seems to play a negative role especially in relation to sex, murder, firearms and total crimes specifications. This indicates that, in general, exchange rate and crime level are the major determining factors of tourist visit for holiday purposes from Central \& South America.

Table 7: Estimated long-run results for North European tourists

\begin{tabular}{|c|c|c|c|c|c|c|}
\hline & \multicolumn{6}{|c|}{ Dependent variable: North European tourists inflows } \\
\hline & Model 1 & Model 2 & Model 3 & Model 4 & Model 5 & Model 6 \\
\hline World GDP (Proxy: & $-0.36^{* * *}$ & $-0.22^{* *}$ & $-0.23^{*}$ & -0.06 & $-0.26^{* * *}$ & $-0.34^{* * * *}$ \\
\hline weighted unemployment) & $(-7.86)$ & $(-3.26)$ & $(-2.27)$ & $(-0.43)$ & $(-5.00)$ & $(-4.52)$ \\
\hline Real exchange rate $(\mathrm{R} / \$)$ & $0.56^{* * *}$ & $0.41^{* * *}$ & $0.38^{* *}$ & $0.41^{* *}$ & $0.66^{* * *}$ & $0.44^{* * *}$ \\
\hline & $(5.53)$ & $(7.12)$ & $(2.76)$ & $(3.50)$ & $(6.11)$ & $(6.68)$ \\
\hline Total crime & $0.36^{* *}$ & & & & & \\
\hline & $(2.63)$ & & & & & \\
\hline Car hijack & & $0.23^{* *}$ & & & & \\
\hline Firearms & & & -0.09 & & & \\
\hline & & & $(-0.44)$ & & & \\
\hline Kidnap & & & & $-0.27^{*}$ & & \\
\hline & & & & $(-1.95)$ & & \\
\hline Murder & & & & & $0.2^{*}$ & \\
\hline & & & & & $(2.16)$ & \\
\hline Sex & & & & & & 0.07 \\
\hline & & & & & & $(0.31)$ \\
\hline Constant & 4.03 & 7.54 & 9.83 & 11.14 & 6.87 & 8.07 \\
\hline
\end{tabular}

Note: *** Significant at $1 \%$ level; ${ }^{* *}$ Significant at $5 \%$ level; * Significant at $10 \%$ level

Source: Author's calculations and analysis of data

In general, tourists from Europe are not negatively affected by the level of crime in the country but instead, their decision to visit the country for holiday is much driven by their level of income and the real exchange of the rand. ${ }^{9}$ Disaggregating European data into three sub-regions found mixed results on tourist reactions to total crime and the categories of crimes analysed in the study. Tourists from Northern Europe are in general tolerant to crime situation in the country. A 1\% rise in total crime level will lead to about $0.36 \%$ increase in tourist inflow from Northern Europe (Table 7). Similar trend will also follow with car hijack $(0.23 \%)$, murder $(0.2 \%)$ and sex $(0.07 \%)$ crimes. Firearms and kidnap crimes are major threat to this group of tourist with about $0.09 \%$ and $0.27 \%$ decline in tourist inflows when these types of crime rises by $1 \%$.

Table 8: Estimated long-run results for South European tourists

\begin{tabular}{|c|c|c|c|c|c|c|}
\hline & \multicolumn{6}{|c|}{ Dependent variable: South European tourists inflows } \\
\hline & Model 1 & Model 2 & Model 3 & Model 4 & Model 5 & Model 6 \\
\hline World GDP & $-0.21 * *$ & $-0.41^{* * *}$ & $-0.28^{* *}$ & $-0.45^{* * *}$ & $-0.31 * * *$ & $-0.29 * *$ \\
\hline weighted unemployment) & $(-3.09)$ & $(-6.18)$ & $(-2.95)$ & $(-5.20)$ & $(-5.13)$ & $(-3.23)$ \\
\hline Real exchange rate $(\mathrm{R} / \$)$ & $0.37^{*}$ & $0.54^{* * *}$ & $0.51^{* *}$ & $0.48^{* * *}$ & $0.30^{*}$ & $0.52^{* * *}$ \\
\hline & $(2.41)$ & $(6.87)$ & $(3.77)$ & $(5.97)$ & $(2.22)$ & $(6.43)$ \\
\hline Total crime & $\begin{array}{l}-0.32 \\
(-1.63)\end{array}$ & & & & & \\
\hline Car hijack & & $\begin{array}{l}-0.39 * * * \\
(-4.29)\end{array}$ & & & & \\
\hline Firearms & & & $\begin{array}{l}-0.12 \\
(-0.66)\end{array}$ & & & \\
\hline Kidnap & & & & $\begin{array}{l}0.18^{*} \\
(2.04)\end{array}$ & & \\
\hline Murder & & & & & $\begin{array}{l}-0.22^{*} \\
(-1.99)\end{array}$ & \\
\hline Sex & & & & & & $\begin{array}{l}0.11 \\
(0.40)\end{array}$ \\
\hline Constant & 11.51 & 9.37 & 7.99 & 5.67 & 9.23 & 6.16 \\
\hline
\end{tabular}

\footnotetext{
${ }^{9}$ Result from our earlier estimations on entire Europe tourist's inflows confirmed this fact.
} 
The scenario differs for Southern Europeans and the results follows similar trend with that of tourists from African and North America. A $1 \%$ increase in the total level of crime will lead to about $0.32 \%$ decline in tourist inflows from South Europe (Table 8). Kidnaps and sex crimes are also not major threats to this group of tourists. Tourist's inflows will continue to rise despite the rising level of kidnaps $(0.18 \%)$ and sex $(0.11 \%)$ crimes in the country. On the other hand, a $1 \%$ increase in car hijack, firearms and murder crimes will lead to about $0.39 \%, 0.12 \%$ and $0.22 \%$ decline in tourist inflows from South Europe respectively.

Table 9: Estimated long-run results for West European tourists

\begin{tabular}{|c|c|c|c|c|c|c|}
\hline & \multicolumn{6}{|c|}{ Dependent variable: West European tourists inflows } \\
\hline & Model 1 & Model 2 & Model 3 & Model 4 & Model 5 & Model 6 \\
\hline $\begin{array}{l}\text { World GDP (Proxy: } \\
\text { weighted unemployment) }\end{array}$ & $\begin{array}{l}-0.51^{* * *} \\
(-17.96)\end{array}$ & $\begin{array}{l}-0.47^{* * *} \\
(-12.89)\end{array}$ & $\begin{array}{l}-0.49 * * * \\
(-14.67)\end{array}$ & $\begin{array}{l}-0.46^{* * *} \\
(-6.13)\end{array}$ & $\begin{array}{l}-0.39 * * * \\
(-10.19)\end{array}$ & $\begin{array}{l}-0.15^{* *} \\
(-2.62)\end{array}$ \\
\hline Real exchange rate $(\mathrm{R} / \$)$ & $\begin{array}{l}0.59 * * * \\
(8.95)\end{array}$ & $\begin{array}{l}0.16^{* * *} \\
(5.71)\end{array}$ & $\begin{array}{l}0.38^{* * *} \\
(7.90)\end{array}$ & $\begin{array}{l}0.31^{* * *} \\
(4.14)\end{array}$ & $\begin{array}{l}0.48^{* * *} \\
(5.90)\end{array}$ & $\begin{array}{l}-0.02 \\
(-0.44)\end{array}$ \\
\hline Total crime & $\begin{array}{l}0.57^{* * *} \\
(6.45)\end{array}$ & & & & & \\
\hline Car hijack & & $\begin{array}{l}0.18^{* *} \\
(3.24)\end{array}$ & & & & \\
\hline Firearms & & & $\begin{array}{l}0.40^{* * *} \\
(5.46)\end{array}$ & & & \\
\hline Kidnap & & & & $\begin{array}{l}0.13 \\
(1.50)\end{array}$ & & \\
\hline Murder & & & & & $\begin{array}{l}0.21^{* *} \\
(2.86)\end{array}$ & \\
\hline Sex & & & & & & $\begin{array}{l}-0.93^{* * *} \\
(-5.24)\end{array}$ \\
\hline Constant & 0.86 & 7.54 & 5.44 & 7.83 & 6.71 & 18.52 \\
\hline
\end{tabular}

Tourist from West Europe reacts positively to all crime in the country except for sexual crime which is found to be a threat to them. A $1 \%$ rise in total crime level will lead to about $0.57 \%$ increase in tourist inflow from Western Europe (Table 9). Similarly, a 1\% rise in car hijack, firearms, kidnap and murder crimes will lead to about $0.18 \%, 0.4 \%, 0.13 \%$ and $0.21 \%$ respectively. On the other hand, Western European tourist inflow will decline by about $0.93 \%$ when sex crime rises by $1 \%$ in the previous period. The different reactions of tourists to the different categories of crimes could be attributed to the similarities or diversities in social environment and culture, and the long-term existence of political and economic ties. For instance, tourist from the middle-east may not respond to the categories of crime in South Africa given the existence of violent political environment in the region. In the same way, the European tourists may not see crime as a serious threat to their decision on holiday trip to South Africa given the historic political and economic ties with South Africa. Table.B1 to B9 in the Appendix presents the short-run adjustment coefficients ( $\alpha$ values or loading matrices), which show the dynamic adjustment towards the long-run equilibrium path. As expected, the $\alpha$ values from the error-correction estimates are all greater than 0 in absolute values. This implies that all the cointegrating vectors enter into the short-run determination of the South African inbound tourism demand function and, therefore, they can be regarded as not being weakly exogenous (Enders, 2004; 328). The negative signs of the loading factors show that all the variables tend to bring back the system to its long-run equilibrium path. On the other hand, the positive signs of the loading factor show that the variables tend to push the system away from its long-run equilibrium path. In general, from all the estimations performed, the real exchange rate of the rand is found not to play a role in returning the long-run tourism demand back to its equilibrium path.

\section{Conclusion}

The focus of the study was to establish the impact of crime on tourist inflows into South Africa. Given the disparity in the nature of criminal offences, the study further investigated the impact of five major crimes as highlighted in Ferreira and Harmse (2000). In line with the exiting empirical literature, the results from the study confirm that income level, real exchange rate (measure of domestic prices) and crime levels are significant determinants of tourist inflows into South Africa. Empirical studies on the impact of 
crime on tourism demand in Africa and particularly in South Africa are still rare likewise is the question whether the geographical disparities in tourist inflows to the country influenced by the levels of crime still remains ambiguously answered. The results for all tourists from all regions are found to be statistically and economically significant and are consistent with the theoretical specification. Tourists are more concerned with the firearms and murder crimes level in the country. With regards to tourists from other African countries, global economic activity and exchange rate fluctuations remained significant factors in the decision of tourists visit for a holiday in South Africa. Kidnaps and sex crimes are not major threats to African tourists. However tourists from Asia are more negatively affected by the level of sex crime in the country. The impact of crime on tourist inflows to the country from the middle-east is found to be statistically insignificant across the major types of crimes and the level of crime in the country does not negatively influence middle-east tourist's inflows. Results for tourists from North America follows similar trend with that of African tourists except that the impact is larger at the total crime level and in some other types of crime. Tourist inflows from Central \& South America are negatively affected by all the types of crime in the country except for kidnap. In general, tourists from Europe are not negatively affected by the level of crime in the country but instead, their decision to visit the country for holiday is much driven by their level of income and the real exchange of the rand.

Disaggregating European data into three sub-regions found mixed results on tourist reactions to total crime and the categories of crimes analysed in the study. Tourists from Northern Europe are in general tolerant to crime situation in the country whilst the scenario is different for those from Southern Europe. Tourist from West Europe reacts positively to all crimes in the country except for sexual crime which is found to be a threat to them. There is therefore need for the government and all major players in the tourism industry to encourage an environment that make visitors stay in the country memorable and safe. This can be done by improving the quality of infrastructure that not only enhance service quality but also deters crime. Police visibility in general and in crime prone tourist attractions in particular should be encouraged so that safety and security is enhanced.

\section{References}

Alam, M. \& Quazi, R. (2003). Determinant of Capital Flight: An Econometric Case Study of Bangladesh. International Review of Applied Economics, 17, 85-103

Altindag, D. T. (2010). Crime and International Tourism. Working Paper, Department of Economics Louisiana State University.

Ang, J. (2009). Financial development and the FDI-growth nexus: the Malaysian experience. Applied Economics, 41(13), 1595-1601.

Biagi, B. \& Detotto, C. (2010). Crime as tourism externality. Working Paper 2010/15. Centre for North South Economic Research .

Biagi, B., Giovana, M. B. \& Detotto, C. (2012). The Effect of Tourism on Crime in Italy: A Dynamic Panel Approach. Economics Discussion Papers, No. 2012-4, http://hdl.handle.net/10419/54945.

Boxill, I. (1995). Crime and Sustainable Tourism in Jamaica. Unpublished paper, University of the West Indies, Mona, Jamaica.

Boxill, I. \& Alleyne, D. (2003). The Impact of Crime on Tourist Arrivals in Jamaica. International Journal of Tourism Research, 5, 381-391

Cleverdon, R. G. (2002). Tourism Development in the SADC Region: the opportunities and challenges. Development Southern Africa, 19(1), 7-28.

Corman, H. \& Mocan, N. (2000). A Time-Series Analysis of Crime, Deterrence and Drug Abuse in New York City. American Economic Review, 90(3), 584-604

COMESA. (2011). Shaping the Future of Tourism in COMESA: http://www.comesa.int/index.php?option=com_content\&view=article\&id=337:shaping-thefuture-of-tourism-in-comesa\&catid=26:other-news\&Itemid=48: accessed 20/02/2013

Duncan, R. \& Lawson, T. (1997). Cost structures in Papua New Guinea. Discussion Paper, No. 69, Institute of National Affairs, Port Moresby

De Albuqueque, K. \& McElroy, J. (1999). Tourism and crime in the Caribbean. Annals of Tourism Research, 26(1), 968-984.

DTI Investor Handbook. (2010): http://www.weforum.org/reports/travel-tourism-competitivenessreport-2009. Accessed 18/02/1013

Eilat, Y. \& Einav, L. (2003). The determinants of international tourism: a three-dimensional panel data analysis', unpublished working paper. 
Engle, R. F. \& Granger, C. (1987). Co-integration and Error Correction: Representation, Estimation and Testing. Econometrica, 55, 251-276.

Ferreira, S. \& Harmse, A. (2000). Crime and Tourism in South Africa: International Tourist Perception Risk. South African Geographical Journal, 82(2), 80-85.

George, R. (2002). Marketing South African Tourism and Hospitality, Cape Town, Oxford University Press. Government of South Africa Department of Trade and Industry (DTI). (2006). Tourism sector report

Harper, D. W. (2000). Planning in tourist robbery. Annals of Tourism Research, 27(2), 517-20

IMF. (2008). International Financial Statistics Online: http://www.imfstatistics.org/imf

Johansen, S. (1988). Statistical analysis of cointegrating vectors. Journal of Economic Dynamics and Control, 12, 231-254.

Jud, D. G. (1975). Tourism and Crime in Mexico. Social Sciences Quarterly, 56, 324-330.

Kester, I. (2003). International Tourism in Africa. Tourism Economics, 9(2), 203-221

Kim, S. \& Song, H. (1998). Analysis of inbound tourism demand in South Korea: a co-integration and error correction approach. Tourism Analysis, 3, 25-41.

Levantis, T. \& Gani, A. (2000). Tourism Demand and the Nuisance of Crime. International Journal of Social Economics, 27, 959-67

Levitt, S. (1998). Juvenile Crime and Punishment. Journal of Political Economy, 106, 1156-85.

Lew, A. (1987). A Framework for Tourist attraction Research. Annals of Tourism Research, 14, 553-575

Mah, J. S. (2000). An empirical examination of the disaggregated import demand of Korea- the case of information technology products. Journal of Asian Economics, 11, 237-244.

Martin, C. A. \& Witt, S. F. (1987). Tourism demand forecasting models: Choice of appropriate variable to represent tourists' cost of living. Tourism Management, 8(3), 233-245.

Mitchell, J. \& Ashley, C. (2006). Can tourism help reduce poverty in Africa. Overseas Development Institute, London

McPheters, L. R. \& Strange, W. B. (1974). Crime as an Environmental Externality of Tourism: Florida. Land Economics, 50, 288-292.

Mocan, H. N., Billups, S. C. \& Overland, J. (2005). A Dynamic Model of Differential Human Capital and Criminal Activity. Economica, 72, 655-681.

Moyo, B. \& Ziramba, E. (2013). Impact of Crime on Inbound Tourism to South Africa, An application of the Bounds test. African Security Review, 22(1), 4-18

Muchapondwa, E. \& Pimhidzai, O. (2011). Modeling International Tourism Demand for Zimbabwe. International Journal of Business and Social Science, 2(2), 71-81

Narayan, P. K. \& Narayan, S. (2005). Estimating income and price elasticities of imports for Fiji in a cointegration framework. Economic Modelling, 22, 423-438.

Naude, W. \& Saayman, A. (2005). Determinants of tourist arrivals in Africa: a panel data regression analysis. Tourism Economics, 11(3), 365-391

Nkosi, G. S. (2010). The Impact of Crime on Tourism in the City of uMhlathuze, KwaZulu-Natal. South Asian Journal of Tourism and Heritage, 3(2), 76-81

Pesaran, M. H. \& Pesaran, B. (1997). Working with Microfit 4.0. Camfit Data Ltd. Cambridge.

Pesaran, M. H., Shin, Y. \& Smith, R. J. (2000). Bounds Testing Approaches to the Analysis of Level Relationships. Journal of Applied Econometrics, 16(3), 289-326.

Phillips, P. C. B. \& Perron, P. (1988). Testing for a unit root in time series regression. Biometrika, 75, 335-46

Pizam, A. \& Telisman-Kosuta, N. (1989). Tourism as a Factor of Change: Results and Analysis. In Tourism as a Factor of Change: A Socio-Cultural Study, J. Bytstrzanowski, ed., pp. 60-63. Vienna: Vienna Centre.

Pizam, A. \& Mansfeld, Y. (1996). Tourism, Crime and International, Security Issues. New York. John Wiley \& Sons.

Pizam, A. (1982). Tourism and Crime: Is There a Relationship? Journal of Travel Research, 20, 7-10.

Quantec database: http://www.easydata.co.za

Ryan, C. (1993). Crime, Violence, Terrorism and Tourism. Tourism Management, 14, 173 - 183.

Ryan, C. (1993). Crime, violence, terrorism and tourism: an accidental or intrinsic relationship? Tourism Management, 14(3), 173-83

South African Police Services (SAPS). (2011). http://www.issafrica.org /crimehub/uploads/10_crime_challenge_saps.pdf. accessed 01/02/1013

Saayman, A., Saayman, M. \& Naudé, W. A. (2000). The impact of tourist spending in Southern Africa: spatial implications. South African Journal of Economic and Management Sciences, 3 (3), 369-386.

Saayman, A. \& Saayman, M. (2008). Determinants of inbound Tourism to South Africa. Tourism Economics, 14(1), 81-96.

South African Reserve Bank (SARB) Statistics 
Song, H., Wong, K. \& Chon, K. (2003). Modeling and forecasting the demand for Hong Kong tourism. Hospitality Management, 22, 435-451.

Statistics South Africa. (2003 -2011). Monthly Tourism and Migration reports.

Tan, A. Y., MCcahon, C. \& Miller, J. (2002). Modeling tourist flows to Indonesia and Malaysia. Journal of Travel and Tourism Marketing, 13(1/2), 63-84.

United Nations World Tourism Organization (UNWTO). (2006). Tourism Trends, 2005 Edition. UNWTO: New York

Vanegas, M. \& Croes, R. (2000). Evaluation of demand: US tourism in Aruba. Annals of Tourism Research, 27, 946-963.

Witt, S. F. \& Witt, C. A. (1992). Tourism Demand: Literature review and econometric model specification. In Modeling and Forecasting Demand in Tourism (16-29). San Diego: Academic Press Inc.

World Travel and Tourism Council. (2012). http://www.wttc.org/research/economic-impactresearch/regional-reports/ accessed 05/03/2013

Ziramba, E. (2008). The demand for residential electricity in South Africa. Energy Policy, 36, 3460-3466.

\section{Appendix}

Table A1: Contribution of Travel and Tourism on the World economy

\begin{tabular}{|c|c|c|c|c|c|c|c|c|c|}
\hline USD bn & & 2006 & 2007 & 2008 & 2009 & 2010 & 2011 & 2012E* & $2020 F^{* *}$ \\
\hline $\begin{array}{l}\text { Direct contribution } \\
\text { Travel and Tourisn } \\
\text { to GDP }\end{array}$ & & 1.911 .5 & 1.967 .1 & 1.921 .5 & 1.862 .6 & 1.916 .1 & 1.972 .8 & 2.028 .2 & 3.056 .2 \\
\hline $\begin{array}{l}\text { Total contribution } \\
\text { travel and Tourism } t \\
\text { GDP }\end{array}$ & & 6.032 & 6.264 & 6.280 & 6.033 & 6.171 & 6.346 & 6.527 & 9.940 \\
\hline $\begin{array}{l}\text { Direct Contribution t } \\
\text { Employment }\end{array}$ & & $\begin{array}{l}100,07 \\
2\end{array}$ & 99,388 & 99,523 & 96,593 & 96,831 & 98,031 & 100,292 & 120,470 \\
\hline $\begin{array}{l}\text { Total contribution } t \\
\text { employment }\end{array}$ & 0 & $\begin{array}{l}265,47 \\
9\end{array}$ & 272,726 & $\begin{array}{l}263,10 \\
4\end{array}$ & 255,299 & 251,512 & 254,941 & 260,093 & 327,922 \\
\hline $\begin{array}{l}\text { Direct } \\
\text { contribution to } \\
\text { GDP }\end{array}$ & 3.8 & & 2.9 & -2.3 & -3.1 & $2.9^{\text {GRO }}$ & $\begin{array}{l}\text { TH RATE } \\
3.0\end{array}$ & 2.8 & 4.2 \\
\hline $\begin{array}{l}\text { Total contribution } \\
\text { to GDP }\end{array}$ & 4.1 & & 3.8 & 0.3 & -3.9 & 2.3 & 2.8 & 2.8 & 4.3 \\
\hline $\begin{array}{l}\text { Direct } \\
\text { contribution to } \\
\text { employment }\end{array}$ & 3.9 & & -0.7 & 0.1 & -3.9 & 2.3 & 2.8 & 2.8 & 4.3 \\
\hline $\begin{array}{l}\text { Total contribution } \\
\text { to employment. }\end{array}$ & 3.3 & & 2.7 & -3.5 & -3.0 & -1.5 & 1.4 & 2.0 & 2.3 \\
\hline
\end{tabular}

Source: World Travel and Tourism Council, 2012; * estimate, ${ }^{* *}$ Forecast

Table A2: Travel and Tourism Descriptive Statistics for Sub Saharan Africa

\begin{tabular}{|c|c|c|c|c|c|c|c|c|}
\hline USD bn real 2012 prices & 2007 & 2008 & 2009 & 2010 & 2011 & 2012 & 2013E* & $2020 \mathrm{~F}^{* *}$ \\
\hline Visitor exports & 28.0 & 27.8 & 26.1 & 26.9 & 28.1 & 29.8 & 30.5 & 47.3 \\
\hline Direct contribution to GDP & 32.0 & 33.2 & 32.6 & 32.7 & 34.3 & 36.0 & 37.5 & 61.9 \\
\hline Capital Investments & 15.2 & 15.8 & 14.7 & 13.6 & 14.0 & 14.6 & 15.2 & 23.2 \\
\hline Total contribution to GDP & 86.0 & 88.5 & 88.2 & 86.6 & 89.8 & 94.3 & 98.2 & 161.8 \\
\hline $\begin{array}{l}\text { Direct Contribution to } \\
\text { Employment }\end{array}$ & $5,134.3$ & $5,397.0$ & $5,142.7$ & $4,940.4$ & $5,336.1$ & $5,457.8$ & $5,580.3$ & $6,956.2$ \\
\hline $\begin{array}{l}\text { Total contribution to } \\
\text { employment }\end{array}$ & $\begin{array}{l}12,655 . \\
8\end{array}$ & $\begin{array}{l}13,117 . \\
5\end{array}$ & $\begin{array}{l}12,790 . \\
7\end{array}$ & $\begin{array}{l}12,039 . \\
2\end{array}$ & $\begin{array}{l}12,784 . \\
3 \\
\text { GROWT }\end{array}$ & $\begin{array}{l}13,129 . \\
0 \\
\text { RATES }\end{array}$ & $\begin{array}{l}13,457 . \\
5\end{array}$ & $16,952.3$ \\
\hline Visitor exports & 9.5 & -0.6 & -6.3 & 3.0 & 4.6 & 6.1 & 2.4 & 4.5 \\
\hline $\begin{array}{l}\text { Direct contribution to } \\
\text { GDP }\end{array}$ & 12.3 & 3.8 & -2.0 & 0.4 & 5.0 & 4.9 & 4.2 & 5.1 \\
\hline $\begin{array}{l}\text { Total contribution to } \\
\text { GDP }\end{array}$ & 12.9 & 2.9 & -0.4 & -1.8 & 3.7 & 5.1 & 4.1 & 5.1 \\
\hline $\begin{array}{l}\text { Direct contribution to } \\
\text { employment }\end{array}$ & 11.0 & 5.1 & -4.7 & -3.9 & 8.0 & 2.3 & 2.2 & 2.2 \\
\hline $\begin{array}{l}\text { Total contribution to } \\
\text { Employment }\end{array}$ & 13.2 & 3.6 & -2.5 & -5.9 & 6.2 & 2.7 & 2.5 & 2.3 \\
\hline
\end{tabular}




\begin{tabular}{|c|c|c|c|c|c|c|c|c|}
\hline Capital Investment & & & 7.2 & -7.6 & 3.4 & 4.2 & 3.8 & 4.3 \\
\hline \multicolumn{9}{|c|}{$\begin{array}{l}\text { Source: World Travel and Tourism Council, } 2012 ;{ }^{*} \text { estimate, }{ }^{* *} \text { Forecast } \\
\text { Table A3: Travel and Tourism Descriptive Statistics for South Africa }\end{array}$} \\
\hline ZAR bn: real 2012 prices & 2007 & 2008 & 2009 & 2010 & 2011 & 2012 & 2013E* & $2020 F^{* *}$ \\
\hline Visitor exports & 101.7 & 98.6 & 88.2 & 84.9 & 82.5 & 93.7 & 95.9 & 150.3 \\
\hline Direct contribution to GDP & 90.4 & 90.3 & 86.5 & 92.3 & 94.0 & 102.0 & 103.7 & 161.4 \\
\hline Capital Investments & 57.7 & 64.3 & 57.2 & 48.3 & 49.6 & 52.1 & 53.1 & 74.9 \\
\hline Total contribution to GDP & 293.2 & 291.1 & 285.4 & 291.3 & 294.0 & 315.4 & 321.5 & 492.7 \\
\hline \multicolumn{8}{|l|}{ Employment } & 786.5 \\
\hline $\begin{array}{l}\text { Total contribution } \\
\text { employment }\end{array}$ & 1407.5 & 1423.7 & 1344.8 & 1315.1 & 1298.9 & 1399.6 & 1415.3 & 1749.7 \\
\hline \multicolumn{9}{|c|}{ GROWTH RATES } \\
\hline Visitor exports & 7.1 & -3.0 & -10.6 & -3.8 & -2.8 & 13.6 & 2.3 & 4.6 \\
\hline Direct contribution to GDP & 4.5 & -0.1 & -4.3 & 6.7 & 1.9 & 8.5 & 1.7 & 4.5 \\
\hline Total contribution to GDP & 6.4 & -0.7 & -2.0 & 2.1 & 0.9 & 7.3 & 1.9 & 4.4 \\
\hline $\begin{array}{l}\text { Direct contribution to } \\
\text { employment }\end{array}$ & 1.9 & 2.9 & -9.5 & 1.6 & 0.3 & 8.7 & 0.5 & 2.4 \\
\hline $\begin{array}{l}\text { Total contribution } \\
\text { Employment }\end{array}$ & 2.3 & 1.2 & -5.5 & -2.2 & -1.2 & 7.8 & 1.1 & 2.1 \\
\hline
\end{tabular}

Source: World Travel and Tourism Council, 2012; * estimate, ** Forecast

Table A4: Number of reported crime cases in South Africa

\begin{tabular}{|c|c|c|c|c|c|c|c|c|}
\hline & 2003 & 2004 & 2005 & 2006 & 2007 & 2008 & 2009 & 2010 \\
\hline TOURISTS INFLOWS & $\begin{array}{l}664 \\
0095\end{array}$ & 6815196 & 7518317 & $\begin{array}{l}850 \\
8805\end{array}$ & 9207697 & 9728860 & $\begin{array}{l}100 \\
98306\end{array}$ & $\begin{array}{l}115 \\
74540\end{array}$ \\
\hline SERIOUS & 272 & 2526689 & 2311392 & 222 & 2168013 & 2185410 & 216 & 214 \\
\hline CRIMES & 9317 & & & 5030 & & & 2672 & 7595 \\
\hline $\begin{array}{l}\text { Murder and } \\
\text { attempted murder }\end{array}$ & 39152 & 44332 & 40104 & 39328 & 37548 & 37150 & 34763 & 32354 \\
\hline Total sexual crimes & 48798 & 68648 & 68817 & 65414 & 61667 & 70770 & 68354 & 68122 \\
\hline $\begin{array}{l}\text { Common assault } \\
\text { and assault to inflict } \\
\text { grievous bodily } \\
\text { harm }\end{array}$ & 408894 & 277526 & 468466 & 427104 & 399802 & 401472 & 396291 & 393268 \\
\hline Common robbery & 73392 & 92706 & 77304 & 72849 & 65756 & 60640 & 57858 & 55476 \\
\hline Car hijackings & 10845 & 12699 & 12242 & 13792 & 13878 & 14793 & 14510 & 11313 \\
\hline $\begin{array}{l}\text { Theft of and from } \\
\text { motor vehicles }\end{array}$ & 200007 & 237459 & 224995 & 215794 & 196541 & 183338 & 194448 & 177288 \\
\hline $\begin{array}{l}\text { Illegal possession of } \\
\text { fire arms }\end{array}$ & 13032 & 15788 & 13589 & 14354 & 13657 & 13882 & 14443 & 14320 \\
\hline Drug related crime & 46256 & 76915 & 94461 & 101395 & 107810 & 115380 & 128883 & 149199 \\
\hline Culpable homicide & 8652 & 11745 & 12491 & 12535 & 13312 & 12658 & 12301 & 12083 \\
\hline Public Violence & 729 & 948 & 1070 & 1037 & 927 & 1282 & 1353 & 1203 \\
\hline Kidnapping & 2246 & 2748 & 2398 & 2299 & 2384 & 2439 & 2710 & 3476 \\
\hline Crimen Injuria & 43958 & 57442 & 47172 & 38539 & 33886 & 31314 & 30978 & 34279 \\
\hline
\end{tabular}

Source: Authors' own calculations based on the South African Police Service statistics. The 2003 statistics only cover period April to December

Figure 1: 


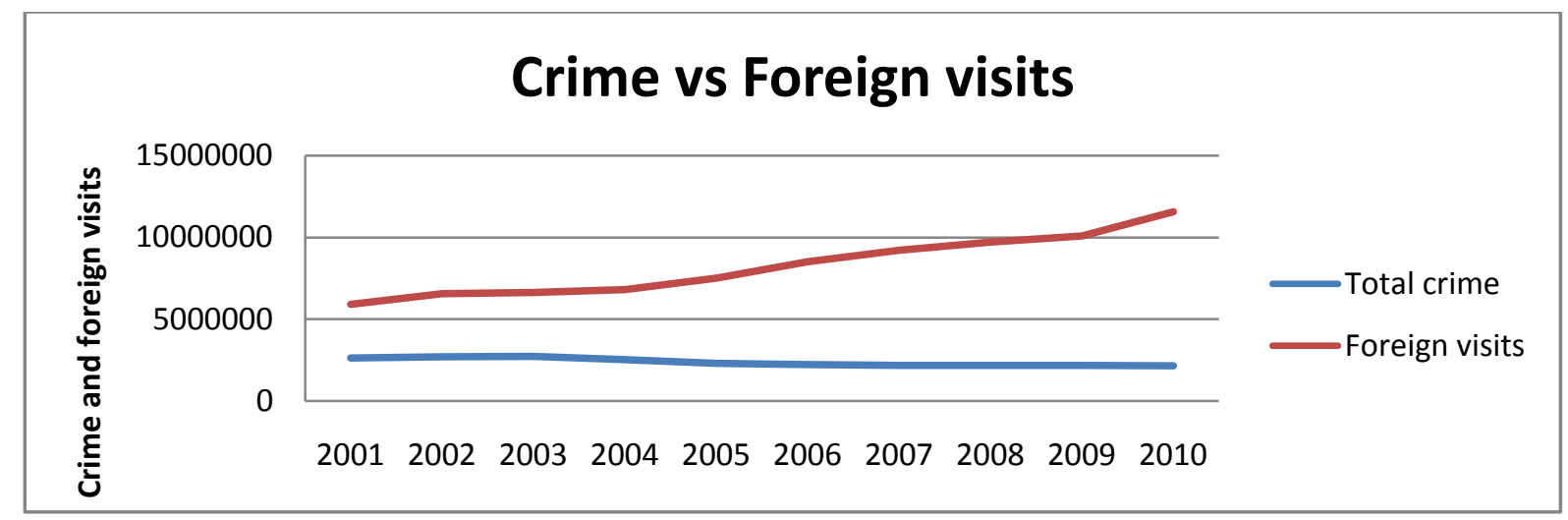

Source: Stats SA and Quantec databses

Figure 2:

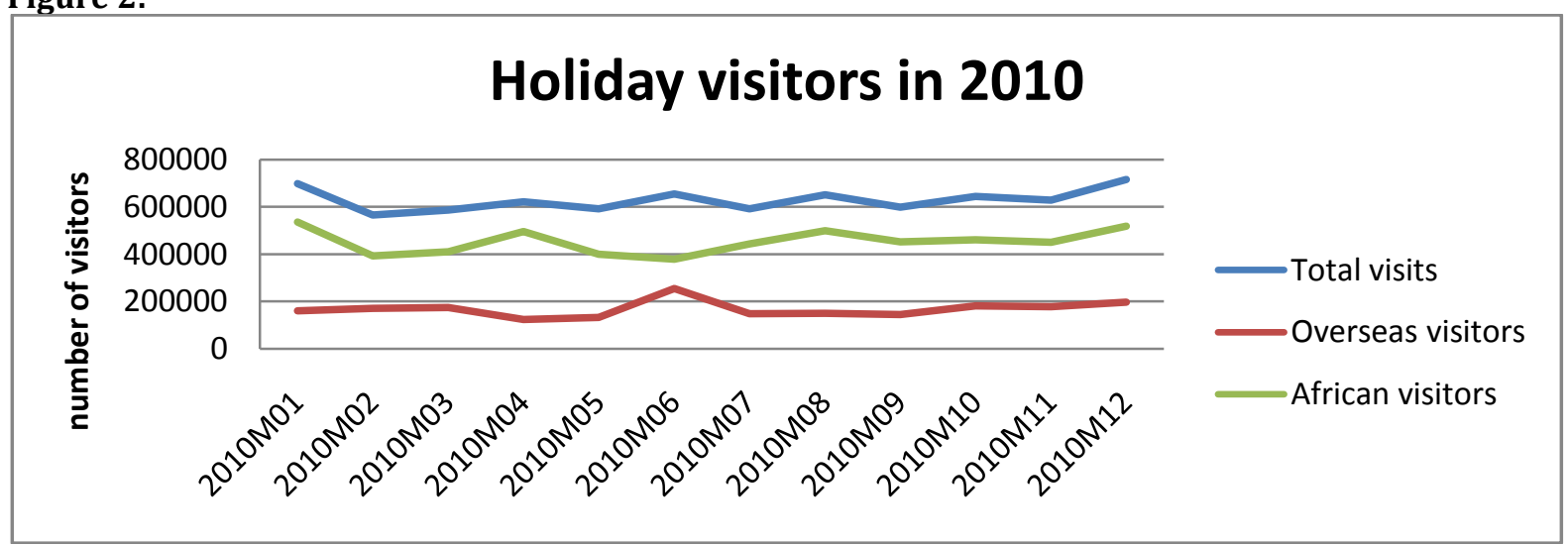

Source: Stats SA

Estimated loading matrices and weak exogeneity tests

Table B1: Error Correction Estimates for All Tourists from All Regions

\begin{tabular}{|c|c|c|c|c|}
\hline Error Correction: & $\Delta$ (Total tourists) & $\Delta$ (World GDP) & $\Delta$ (Real R/\$) & $\Delta$ (Crime $(-1))$ \\
\hline \multirow[t]{3}{*}{ Equation 1} & -0.602465 & -0.051857 & 0.119322 & -0.243212 \\
\hline & $(0.09673)$ & $(0.03898)$ & $(0.05481)$ & $(0.04974)$ \\
\hline & {$[-6.22845]$} & {$[-1.33045]$} & [2.17718] & {$[-4.89009]$} \\
\hline \multirow[t]{3}{*}{ Equation 2} & -0.333810 & -0.130781 & 0.130987 & 0.051621 \\
\hline & $(0.12416)$ & $(0.03922)$ & $(0.06714)$ & $(0.11402)$ \\
\hline & {$[-2.68855]$} & {$[-3.33490]$} & [1.95092] & {$[0.45274]$} \\
\hline \multirow[t]{3}{*}{ Equation 3} & -0.913358 & 0.017343 & 0.090610 & -0.223086 \\
\hline & $(0.17352)$ & $(0.05405)$ & $(0.09620)$ & $(0.16540)$ \\
\hline & {$[-5.26370]$} & [0.32088] & [0.94189] & {$[-1.34875]$} \\
\hline \multirow[t]{3}{*}{ Equation 4} & -0.415589 & -0.034251 & 0.051829 & -0.175409 \\
\hline & $(0.06982)$ & $(0.02692)$ & $(0.03601)$ & $(0.10082)$ \\
\hline & {$[-5.95237]$} & {$[-1.27210]$} & [1.43939] & {$[-1.73978]$} \\
\hline \multirow[t]{3}{*}{ Equation 5} & -0.581555 & 0.024234 & 0.273884 & -0.699951 \\
\hline & $(0.20843)$ & $(0.06678)$ & $(0.09682)$ & $(0.19672)$ \\
\hline & {$[-2.79020]$} & {$[0.36290]$} & [2.82880] & {$[-3.55815]$} \\
\hline \multirow[t]{3}{*}{ Equation 6} & -0.366947 & -0.101836 & 0.080534 & -0.191787 \\
\hline & $(0.08382)$ & $(0.02534)$ & $(0.03950)$ & $(0.09487)$ \\
\hline & {$[-4.37786]$} & {$[-4.01897]$} & [2.03868] & {$[-2.02167]$} \\
\hline
\end{tabular}

Source: Authors calculations

Table B2: Error Correction Estimates for African Tourists

\begin{tabular}{lllll}
\hline Error Correction: & $\Delta$ (Africa tourists) & $\Delta$ (World GDP) & $\Delta$ (Real R/\$) $\Delta$ (Crime(-1)) \\
\hline Equation 1 & -0.826650 & -0.201978 & 0.260266 & -0.134214
\end{tabular}




$\begin{array}{ccccc} & (0.34011) & (0.11292) & (0.17010) & (0.18042) \\ \text { Equation 2 } & {[-2.43051]} & {[-1.78866]} & {[1.53004]} & {[-0.74390]} \\ & -0.141502 & -0.144037 & 0.100289 & 0.154879 \\ \text { Equation 3 } & (0.10815) & (0.03232) & (0.04968) & (0.09604) \\ & {[-1.30843]} & {[-4.45626]} & {[2.01861]} & {[1.61267]} \\ \text { Equation 4 } & -0.686556 & -0.239921 & 0.112399 & -0.141560 \\ & (0.24504) & (0.06424) & (0.12050) & (0.26656) \\ & {[-2.80183]} & {[-3.73469]} & {[0.93280]} & {[-0.53106]} \\ \text { Equation 5 } & -0.078015 & -0.081726 & 0.077987 & -0.284637 \\ & (0.07908) & (0.02379) & (0.03351) & (0.09460) \\ & {[-0.98651]} & {[-3.43571]} & {[2.32728]} & {[-3.00873]} \\ \text { Equation 6 } & -0.988056 & -0.369508 & 0.319860 & -0.276206 \\ & (0.37324) & (0.11672) & (0.16529) & (0.39569) \\ & {[-2.64726]} & {[-3.16563]} & {[1.93510]} & {[-0.69804]} \\ & -0.126618 & -0.219984 & 0.172090 & -0.457994 \\ \text { Source: Authors } & (0.20541) & (0.05628) & (0.10075) & (0.23640) \\ & {[-0.61642]} & {[-3.90868]} & {[1.70815]} & {[-1.93739]}\end{array}$

Source: Authors calculations

Table B3: Error Correction Estimates for Asian Tourists

\begin{tabular}{|c|c|c|c|c|}
\hline Error Correction: & $\Delta$ (Asian tourists) & $\Delta$ (World GDP) & $\Delta$ (Real R/\$) & $\Delta$ (Crime $(-1))$ \\
\hline \multirow[t]{3}{*}{ Equation 1} & -0.395348 & -0.009384 & 0.018213 & -0.212013 \\
\hline & $(0.20818)$ & $(0.03526)$ & $(0.06328)$ & $(0.05939)$ \\
\hline & {$[-1.89903]$} & {$[-0.26617]$} & {$[0.28781]$} & {$[-3.56977]$} \\
\hline \multirow[t]{3}{*}{ Equation 2} & -0.480193 & -0.154405 & 0.010888 & 0.086259 \\
\hline & $(0.16771)$ & $(0.03883)$ & $(0.05721)$ & $(0.11962)$ \\
\hline & {$[-2.86329]$} & {$[-3.97615]$} & [0.19031] & {$[0.72111]$} \\
\hline \multirow[t]{3}{*}{ Equation 3} & -0.441763 & -0.104394 & 0.007543 & -0.189310 \\
\hline & $(0.12039)$ & $(0.02652)$ & $(0.04104)$ & $(0.08265)$ \\
\hline & {$[-3.66938]$} & {$[-3.93673]$} & [0.18382] & {$[-2.29063]$} \\
\hline \multirow[t]{3}{*}{ Equation 4} & -0.430036 & -0.291682 & -0.059135 & -0.264168 \\
\hline & $(0.26955)$ & $(0.04818)$ & $(0.08044)$ & $(0.21117)$ \\
\hline & [-1.59539] & {$[-6.05413]$} & {$[-0.73518]$} & {$[-1.25095]$} \\
\hline \multirow[t]{3}{*}{ Equation 5} & -0.446228 & 0.103424 & -0.102735 & -0.223698 \\
\hline & $(0.25322)$ & $(0.04593)$ & $(0.07547)$ & $(0.15910)$ \\
\hline & {$[-1.76221]$} & [2.25158] & {$[-1.36134]$} & {$[-1.40604]$} \\
\hline \multirow[t]{3}{*}{ Equation 6} & -0.365326 & 0.002011 & 0.060704 & -0.526962 \\
\hline & $(0.16790)$ & $(0.03097)$ & $(0.04875)$ & $(0.10595)$ \\
\hline & {$[-2.17589]$} & [0.06493] & [1.24528] & {$[-4.97366]$} \\
\hline
\end{tabular}

Source: Authors calculations

Table B4: Error Correction Estimates for Middle East Tourists

\begin{tabular}{|c|c|c|c|c|}
\hline Error Correction: & $\Delta$ (Middle East tourists) & $\Delta$ (World GDP) & $\Delta$ (Real R/\$) & $\Delta$ (Crime $(-1))$ \\
\hline \multirow[t]{3}{*}{ Equation 1} & -0.295923 & -0.022711 & 0.154737 & -0.071541 \\
\hline & $(0.21883)$ & $(0.02492)$ & $(0.04489)$ & $(0.04721)$ \\
\hline & {$[-1.35229]$} & {$[-0.91128]$} & [3.44717] & {$[-1.51533]$} \\
\hline \multirow[t]{3}{*}{ Equation 2} & -0.539618 & 0.040786 & 0.245802 & 0.219402 \\
\hline & $(0.36219)$ & $(0.04941)$ & $(0.07838)$ & $(0.15506)$ \\
\hline & {$[-1.48989]$} & {$[0.82551]$} & [3.13612] & [1.41494] \\
\hline \multirow[t]{3}{*}{ Equation 3} & -0.794853 & -0.019689 & 0.238694 & 0.256565 \\
\hline & $(0.33130)$ & $(0.04533)$ & $(0.07270)$ & $(0.15234)$ \\
\hline & {$[-2.39917]$} & {$[-0.43436]$} & [3.28329] & {$[1.68420]$} \\
\hline \multirow[t]{3}{*}{ Equation 4} & -0.328348 & -0.060077 & 0.035627 & -0.196835 \\
\hline & $(0.12932)$ & $(0.01842)$ & $(0.02749)$ & $(0.07555)$ \\
\hline & {$[-2.53903]$} & {$[-3.26116]$} & [1.29616] & {$[-2.60537]$} \\
\hline \multirow[t]{2}{*}{ Equation 5} & -0.843239 & 0.131076 & 0.064833 & -0.056013 \\
\hline & $(0.40630)$ & $(0.04821)$ & $(0.09154)$ & $(0.19542)$ \\
\hline
\end{tabular}




\begin{tabular}{lcccc} 
& {$[-2.07541]$} & {$[2.71895]$} & {$[0.70827]$} & {$[-0.28663]$} \\
Equation 6 & -0.194978 & 0.014802 & 0.176156 & 0.166401 \\
& $(0.32799)$ & $(0.03334)$ & $(0.05486)$ & $(0.13958)$ \\
& {$[-0.59445]$} & {$[0.44391]$} & {$[3.21129]$} & {$[1.19215]$} \\
\hline
\end{tabular}

Source: Authors calculations

Table B5: Error Correction Estimates for North American Tourists

\begin{tabular}{|c|c|c|c|c|}
\hline Error Correction: & $\begin{array}{l}\Delta \text { (North American } \\
\text { tourists) }\end{array}$ & $\Delta$ (World GDP) & $\Delta($ Real R/\$) & $\Delta$ (Crime(-1)) \\
\hline \multirow[t]{3}{*}{ Equation 1} & -0.318398 & 0.059310 & 0.317088 & -0.107145 \\
\hline & $(0.25938)$ & $(0.04672)$ & $(0.07930)$ & $(0.07611)$ \\
\hline & {$[-1.22754]$} & [1.26941] & [3.99853] & {$[-1.40779]$} \\
\hline \multirow[t]{3}{*}{ Equation 2} & -0.174957 & -0.037115 & 0.379270 & -0.278961 \\
\hline & $(0.27238)$ & $(0.04743)$ & $(0.08464)$ & $(0.15977)$ \\
\hline & {$[-0.64232]$} & {$[-0.78250]$} & [ 4.48086] & {$[-1.74600]$} \\
\hline \multirow[t]{3}{*}{ Equation 3} & -0.317086 & -0.091437 & 0.110422 & 0.023653 \\
\hline & $(0.17940)$ & $(0.03401)$ & $(0.05293)$ & $(0.10178)$ \\
\hline & {$[-1.76752]$} & {$[-2.68855]$} & [2.08634] & {$[0.23241]$} \\
\hline \multirow[t]{3}{*}{ Equation 4} & 0.244161 & -0.111457 & 0.065456 & -0.306948 \\
\hline & $(0.15440)$ & $(0.02528)$ & $(0.04043)$ & $(0.10557)$ \\
\hline & [1.58134] & {$[-4.40820]$} & [1.61901] & {$[-2.90751]$} \\
\hline \multirow[t]{3}{*}{ Equation 5} & -1.289253 & 0.101346 & 0.157134 & -0.478209 \\
\hline & $(0.43415)$ & $(0.09268)$ & $(0.16149)$ & $(0.29485)$ \\
\hline & [-2.96959] & [ 1.09353$]$ & {$[0.97300]$} & {$[-1.62186]$} \\
\hline \multirow{3}{*}{ Equation 6} & -0.077424 & -0.133499 & 0.050288 & -0.308750 \\
\hline & $(0.20120)$ & $(0.03590)$ & $(0.05667)$ & $(0.12256)$ \\
\hline & {$[-0.38481]$} & {$[-3.71829]$} & {$[0.88740]$} & {$[-2.51921]$} \\
\hline
\end{tabular}

Source: Authors calculations

Table B6: Error Correction Estimates for Central \& South American Tourists

\begin{tabular}{|c|c|c|c|c|}
\hline \multirow[b]{2}{*}{ Error Correction: } & \multicolumn{4}{|c|}{$\Delta$ (Central \& South } \\
\hline & American tourists) & $\Delta$ (World GDP) & $\Delta($ Real R/\$) & $\Delta$ (Crime(-1)) \\
\hline \multirow[t]{3}{*}{ Equation 1} & -0.703885 & 0.005232 & 0.097916 & -0.083332 \\
\hline & $(0.22500)$ & $(0.01839)$ & $(0.03057)$ & $(0.02897)$ \\
\hline & {$[-3.12833]$} & {$[0.28456]$} & [3.20307] & {$[-2.87650]$} \\
\hline \multirow{3}{*}{ Equation 2} & -0.474957 & -0.048811 & 0.040090 & 0.065065 \\
\hline & $(0.14146)$ & $(0.01541)$ & $(0.02196)$ & $(0.04434)$ \\
\hline & {$[-3.35753]$} & {$[-3.16682]$} & [1.82553] & {$[1.46740]$} \\
\hline \multirow[t]{3}{*}{ Equation 3} & -0.822048 & 0.007527 & 0.082829 & -0.014891 \\
\hline & $(0.19963)$ & $(0.01766)$ & $(0.02977)$ & $(0.06212)$ \\
\hline & {$[-4.11789]$} & [ 0.42619$]$ & {$[2.78230]$} & {$[-0.23973]$} \\
\hline \multirow[t]{3}{*}{ Equation 4} & -0.337581 & -0.055459 & 0.025487 & -0.164691 \\
\hline & $(0.14778)$ & $(0.01561)$ & $(0.02101)$ & $(0.05549)$ \\
\hline & {$[-2.28442]$} & {$[-3.55175]$} & [1.21288] & {$[-2.96774]$} \\
\hline \multirow{3}{*}{ Equation 5} & -1.088806 & 0.021711 & 0.121547 & -0.299054 \\
\hline & $(0.29438)$ & $(0.02939)$ & $(0.04249)$ & $(0.10668)$ \\
\hline & {$[-3.69860]$} & {$[0.73872]$} & [2.86091] & {$[-2.80334]$} \\
\hline \multirow[t]{3}{*}{ Equation 6} & -0.587379 & 0.003429 & 0.071046 & -0.233285 \\
\hline & $(0.17483)$ & $(0.01596)$ & $(0.02385)$ & $(0.05481)$ \\
\hline & {$[-3.35964]$} & [0.21485] & [2.97872] & {$[-4.25639]$} \\
\hline
\end{tabular}

Source: Authors calculations

Table B7: Error Correction Estimates for North European Tourists

\begin{tabular}{llclc}
\hline Error Correction: & $\Delta$ (North European tourists) & $\Delta$ (World GDP) & $\Delta$ (Real R/\$) & $\Delta$ (Crime(-1)) \\
\hline Equation 1 & -2.614175 & -0.098040 & 0.051825 & 0.034700 \\
& $(0.41034)$ & $(0.07316)$ & $0.13842)$ & {$[0.11112)$} \\
Equation 2 & {$[-6.37083]$} & {$[-1.34006]$} & {$[0.37439]$} & {$[0.31227]$} \\
& -2.616477 & -0.143861 & 0.044593 & 0.596624
\end{tabular}




\begin{tabular}{ccccc} 
& $(0.45174)$ & $(0.07310)$ & $(0.14038)$ & $(0.20291)$ \\
Equation 3 & {$[-5.79200]$} & {$[-1.96802]$} & {$[0.31767]$} & {$[2.94036]$} \\
& -1.425568 & 0.035801 & 0.076124 & -0.033531 \\
Equation 4 & $(0.18325)$ & $(0.03663)$ & $(0.05301)$ & $(0.08227)$ \\
& {$[-7.77930]$} & {$[0.97725]$} & {$[1.43605]$} & {$[-0.40756]$} \\
Equation 5 & -1.309926 & 0.037709 & 0.042875 & -0.180141 \\
& $(0.15691)$ & $(0.03445)$ & $(0.04438)$ & $(0.12354)$ \\
Equation 6 & {$[-8.34825]$} & {$[1.09457]$} & {$[0.96612]$} & {$[-1.45820]$} \\
& -2.153543 & -0.158105 & 0.113840 & -0.378392 \\
& $(0.39158)$ & $(0.07128)$ & $(0.12721)$ & $(0.26239)$ \\
& {$[-5.49961]$} & {$[-2.21809]$} & {$[0.89494]$} & {$[-1.44212]$} \\
& -3.610578 & 0.002323 & 0.588363 & -0.403002 \\
& $(0.90468)$ & $(0.14938)$ & $(0.28582)$ & $(0.59734)$ \\
\hline
\end{tabular}

Source: Authors calculations

Table B8: Error Correction Estimates for South European Tourists

\begin{tabular}{|c|c|c|c|c|}
\hline Error Correction: & $\begin{array}{l}\Delta \text { (South European } \\
\text { tourists) }\end{array}$ & $\Delta$ (World GDP) & $\Delta($ Real R/\$) & $\Delta($ Crime $(-1))$ \\
\hline \multirow[t]{3}{*}{ Equation 1} & -2.260375 & 0.143810 & 0.029328 & -0.081041 \\
\hline & $(0.45483)$ & $(0.06213)$ & $(0.14046)$ & $(0.10378)$ \\
\hline & {$[-4.96966]$} & {$[2.31470]$} & {$[0.20881]$} & {$[-0.78089]$} \\
\hline \multirow[t]{3}{*}{ Equation 2} & -2.790441 & 0.133460 & 0.072545 & -0.581439 \\
\hline & $(0.38638)$ & $(0.04563)$ & $(0.09018)$ & $(0.15348)$ \\
\hline & {$[-7.22194]$} & [2.92491] & {$[0.80442]$} & [-3.78849] \\
\hline \multirow[t]{3}{*}{ Equation 3} & -1.898667 & 0.040043 & 0.017560 & -0.043795 \\
\hline & $(0.27665)$ & $(0.03306)$ & $(0.05920)$ & $(0.10725)$ \\
\hline & {$[-6.86311]$} & [1.21123] & {$[0.29662]$} & {$[-0.40836]$} \\
\hline \multirow[t]{3}{*}{ Equation 4} & -3.338947 & 0.065831 & 0.043298 & 0.453600 \\
\hline & $(0.42116)$ & $(0.05317)$ & $(0.09419)$ & $(0.24648)$ \\
\hline & {$[-7.92805]$} & [1.23823] & {$[0.45966]$} & [1.84031] \\
\hline \multirow[t]{3}{*}{ Equation 5} & -2.791212 & 0.153288 & -0.025617 & -0.153471 \\
\hline & $(0.52765)$ & $(0.06636)$ & $(0.14088)$ & $(0.25490)$ \\
\hline & {$[-5.28988]$} & [2.30998] & {$[-0.18183]$} & {$[-0.60208]$} \\
\hline \multirow[t]{3}{*}{ Equation 6} & -4.405840 & 0.004427 & -0.044096 & -0.042840 \\
\hline & $(0.93151)$ & $(0.10401)$ & $(0.23757)$ & $(0.45852)$ \\
\hline & {$[-4.72981]$} & {$[0.04256]$} & {$[-0.18561]$} & {$[-0.09343]$} \\
\hline
\end{tabular}

Source: Authors calculations

Table B9: Error Correction Estimates for West European Tourists

\begin{tabular}{lcccc}
\hline Error Correction: & D(LN_W_EUROPE) & D(LN_GDP_W) & D(LN_EXCHINF) & D(LN_ALLCRIMES(-1)) \\
\hline Equation 1 & -4.669553 & -0.011156 & -0.014016 & -0.200870 \\
& $(0.79709)$ & $(0.12592)$ & $(0.25661)$ & $(0.20159)$ \\
Equation 2 & {$[-5.85823]$} & {$[-0.08859]$} & {$[-0.05462]$} & {$[-0.99645]$} \\
& -7.206026 & 0.673191 & -0.165322 & 1.341284 \\
& $(1.40149)$ & $(0.21181)$ & $(0.49804)$ & $(0.70355)$ \\
Equation 3 & {$[-5.14167]$} & {$[3.17827]$} & {$[-0.33195]$} & {$[1.90646]$} \\
& -4.890033 & -0.018174 & 0.177153 & 0.029107 \\
Equation 4 & $(0.69910)$ & $(0.09379)$ & $(0.20569)$ & $(0.35849)$ \\
& {$[-6.99475]$} & {$[-0.19378]$} & {$[0.86125]$} & {$[0.08119]$} \\
Equation 5 & -3.619870 & 0.048302 & 0.116741 & -0.177162 \\
& $(0.53983)$ & $(0.07418)$ & $(0.12825)$ & $(0.37408)$ \\
& {$[-6.70554]$} & {$[0.65111]$} & {$[0.91028]$} & {$[-0.47360]$} \\
Equation 6 & -3.669532 & 0.001071 & -0.002717 & -0.709365 \\
& $(0.82523)$ & $(0.12195)$ & $(0.23580)$ & $(0.44128)$ \\
& {$[-4.44670]$} & {$[0.00878]$} & {$[-0.01152]$} & {$[-1.60750]$} \\
& -4.126186 & 0.440452 & -0.288902 & -0.212757 \\
& $(1.04133)$ & $(0.11572)$ & $(0.26970)$ & $(0.52917)$
\end{tabular}


Order of integration for the variables: Since the actual data-generating process is not known, the univariate characteristics of the data was analysed using the Augmented Dickey-Fuller (ADF) tests to establish the order of integration. Following Said and Dickey (1984), the maximum lag structure suggested is a lag order equal to $T^{1 / 3}$. T is the number of observations, which in this case is 95 (monthly 2003 to 2011). Therefore, the maximum lag structure of 5 is used in the testing procedure.

Table C1: Augmented Dickey-Fuller tests for non-stationarity, levels, April 2003 to March 2011

\begin{tabular}{lllll}
\hline Series & Model & Lags & $\tau_{\tau}, \tau_{\mu}, \tau$ & $\phi_{3}, \phi_{1}$ \\
\hline ln_wgdp & Trend & 1 & -1.95 & 2.51 \\
& Constant & 1 & -1.37 & 2.34 \\
ln_rexch & None & 0 & -0.30 & 4.91 \\
& Trend & 1 & -2.69 & 5.57 \\
ln_crime & Constant & 1 & -1.97 & $14.67^{* * *}$ \\
& None & 1 & -0.49 & $16.18^{* * *}$ \\
ln_tourist & Trend & 0 & $-5.41^{* * *}$ & \\
& Constant & 0 & $-4.02^{* *}$ & $9.10^{* * *}$ \\
& None & 4 & -0.78 & $15.02^{* * *}$ \\
\hline
\end{tabular}

Source: Author's calculation

$*(* *)[* * *] \quad$ Significant at a $10(5)[1] \%$ level.

a At a 10(5)[1]\% significance level, the MacKinnon critical values are $-3.16(-3.46)[-4.06]$ when a trend and a constant are included $\left(\tau_{\tau}\right)$, and $-2.58(-2.89)[-3.50]$ when only a constant is included $\left(\tau_{\mu}\right)$, and 1.61(-1.94)[-2.59] when neither is included $(\tau)$. The standard normal critical value is $-1.697(-2.04)[-$ 2.75].

b At a 10(5)[1]\% significance level, the Dickey-Fuller critical values are 5.47(6.49)[8.73] when a trend and a constant are included $\left(\phi_{3}\right)$ and 3.86(4.71)[6.70] when only a constant is included $\left(\phi_{1}\right)$.

The result of the ADF-test for all the variables used in our estimations is reported in Table C1. The first column shows the list of the variables that are tested. The second column (model) shows whether the equation that is estimated for the testing purpose involves a trend and a constant (Trend), a constant only (Constant), or neither a constant nor a trend (None). The third column shows the appropriate number of lags that are used for each model and they are significant at the 10-percent level. The fourth column is the ADF t-statistic, called $\tau_{\tau}$ (for Trend and a Constant), $\tau_{\mu}$ (for only Constant), and $\tau$ (for neither Trend nor Constant). The last column is the F-statistic $\phi_{3}\left(\phi_{1}\right)$, testing whether the trend (constant) is significant under the null hypothesis of no unit root. From the result, it is clear that only crime and tourist variables are found to be trend stationary $I(0)]$ in level form.

Reduced-Form VAR Diagnostic Tests: Table D1 presents other diagnostics tests for the VAR. All the roots have modulus less than one and lie inside the unit circle. The VAR passed all the diagnostic tests, revealing a well-specified model.

Table D1: Diagnostic Test on the Reduced-Form VAR for All Tourists and All Crime Estimated Equation 


\begin{tabular}{|c|c|c|c|c|}
\hline$H_{1}$ & $H_{0}$ & Test & Statistic & Prob. \\
\hline Serial Correlation & $\begin{array}{ll}\text { No } & \text { Serial } \\
\text { Correlation } & \end{array}$ & $\begin{array}{l}\text { LM-Test- } \chi^{2} \\
(\operatorname{lag} 3)\end{array}$ & 22.50 & 0.13 \\
\hline Normality & $\begin{array}{l}\text { Normally } \\
\text { Distributed }\end{array}$ & JB-Joint & 67.36 & 0.41 \\
\hline & Error Term & $\begin{array}{l}\text { Kurtosis-Joint } \\
\text { Skewness-Joint }\end{array}$ & $\begin{array}{l}48.06 \\
19.29\end{array}$ & $\begin{array}{l}0.91 \\
0.18\end{array}$ \\
\hline Heteroschedasticity & $\begin{array}{l}\text { No } \\
\text { Heteroschedasticity }\end{array}$ & $\chi^{2}$ & 389.15 & 0.64 \\
\hline
\end{tabular}

Source: Author's calculation 